


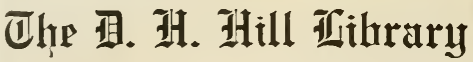

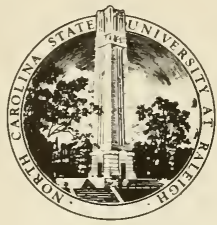

Sinth Caralina $\$$

Special

Collections

SB278

P6

G3 
THIS BOOK MUST NOT BE TAKEN FROM THE LIBRARY BUILDING.

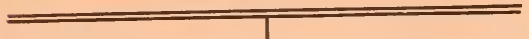







\section{MANUAL}

PARA EL GULTIVO Y BENEFICIO DEL TABACO

EN FILIPINAS. 


\section{MANUAL}

\section{PARA EL GULTIVO}

\section{Y BENEFICIO DEL TABACO}

\section{EN FILIPINAS, \\ POR}

\section{RAFAEL GARCIA LOPEZ,}

Mcalde mayor que fué de varias provincias en aquellas islas,

y Subdelegado de Hacienda pública;

Administrador depositario y C'olector jefe de la de Cagayan;

Visitador é Inspector general de colecciones

agregado á la Secretaria del Ministerio de Ultramar;

Jefe de Administracion civil, é iniciador, primer Jefe organizador para la creacion de la Real Escuela de $\Lambda$ gricultura

y Jardin Botánico en Manila;

Sócio de la Económica de Amigos del País, y Abogado de la Audiencia

y Cancillería Real de Filipinas, etc.

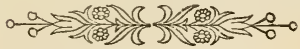

MADRID.

IMPRENTA IIE C. MOLINER Y COMPAÑIA,

Callə de Jesús, Dúm.3. 
Es propiedad del autor, sin cuyo espreso y legal consentimiento no puede reimprimirse ni publicar. 


\section{Sernor \\ MINISTRO DE ULTRAMAR.}

Al redactar este libro, como HANUAL TEÓnICo-prictico para el buen calliro y beneficio del tabaco en Filipinas, resultado de mi personal xperiencin y estudio en la primera euteceion de aquellas islas que á mi cargo esturo, he tenido presente y á ello impulsa recordar el atraso rudimentario en que viene la agricultura de aquel feria Árchipiélagogo.

Yo me jacto, Excelentisimo Seĩor, con el más patriótico orgaullo, de laber inicialo para crearse eu Hanila el actual JuRoIr BOtílico, y ureccion de la Renl escucla de Agricultura leórico-práctica, de cuyos establecimientos oficiales ture la houra seîalada de ser nombrado expontáneamente Jefe organizador en el aino de 1860.

El atraso inpérito, repetiré, con que en Filipinas se signe cultivando y benticiando el nús rico producto del país y que cons ituye la renta principal para los inģiesos del Tesoro público de aquellas islas, es el oljetivo cardinal de mi trabajo, que á $V$. E. sumcto para las urgentes reforma en tan pingüe reuta.

pafaex frarcia Hopez. 



\section{SECCION PRINERA.}

NOCIONES GENERALES dE Agricultura apliCAdaS

al CUltivo deL TABaco.

\section{CAPÍTULO PRIMERO.}

DE LAS HERRAMIENTAS Y APEROS.

Por herramientas agricolas se entiende y son aquellos instrumentos á propósito con que se ayuda el hombre para el cultivo de la tierra, de los árboles y plantas. Tan necesarios son aquellos para dicho objeto, que sin ellas no es posible ejecutar las operaciones agrarias: es más, que no siendo proporcionadas discretamente para el uso respectivo, trabaja mucho más el hombre y no consigue el fin ni la utilidad que pudiera. 
Varias son las herramientas que necesita todo buen labrador para el cultivo del campo y las que, evitándole trabajo, ayudan á su conveniencia $y$ bienestar.

Con efecto; el labrador que carece de alguna de las indispensables para el cultivo y laboreo, valiéndose de otros medios inadecuados, invierte más tiempo, trabaja más, desaprovecha las oportunas favorables circunstancias atmosféricas ó accidentales, desgasta imprudentemente sus fuerzas físicas, se perjudica en la salud y mala, tardía é infructuosamente coje el producto de sus afanes. El que necesita tal herramienta, por ejemplo, $y$ no la tiene ¿no vé, no sabe que no puede ejecutar sin ella la operacion que necesariamente reclama el estado perentorio de su labor? ¿No vé, no sabe que de practicar ó nó tal cosa acrece ó aminora el producto y valor de su cosecha? ¿No la pierde á veces por la falta de una labor oportuna? ¿Cómo ejecutar á tiempo los laboreos y cultivo si no tiene las herramientas necesarias? ¿Cómo aprovechar el tiempo y las oportunas estaciones? ¿Cómo precaverse de los accidentes ó contingencias? ¿Por ventura, es posible al hombre ejecutar con las manos solo, ó con un pedazo de palo, el cultivo de la tierra y de las plantas?

Este error de los filipinos es necesario, á 
toda costa, hacer que entre ellos desaparezca, si la agricultura ha de progresar en aquél país feraz cuanto puede y debe ser. Las malas costumbres se mejoran con la doctrina, el ejemplo y la perseverancia: por ello insistir tanto sobre este particular importante para el buen cultivo del tabaco, cuya planta, si bien fácil de criar, poco delicada y muy agradecida al beneficio, siente mucho el abandono del hombre.

Las herramientas indispensables al labralor dedicado en Filipinas al cultivo del tabaco Cieben ser una buena y grande hacha, azadas, azadones, $\mathrm{h} z \mathrm{z}$ grande $\mathrm{y}$ pequeñas podaderas corvas para el corte y recoleccion. - La primera, con boca ó corte acerado, de bastante peso, bien afilada y con hastil 6 mango de madera algo aplanalo y como de cuatro á cinco palmos de largo. Diclio mango debe entrar á golpe por el ojo del hacha para que quede bien ajustado, con el fin de que los cortes no sean falsos ó inciertos.

El hacha es indispensable para los desmontes ó roturacion de bosques; para cortar maderas de construccion para los camarines de oréo y casa-habitacion; para cortar y hacer estacas con que resguardar las orillas de los terrenos contíguos á rios y esteros: ya, en fin, para surtirse de varias piezas de madera para los 
aperos y demás usos de la labor. El hacha, repito, es necesaria en la casa de todo buen labrador.

La azada debe ser de iguales dimensiones á la que vulgarmente llaman en Filipinas azadon; empero de hierro dulce forjada á martillo en la fragua del herrero y con boca ó corte de buen acero, por tres razones. Primera, porque no teniendo acero en la boca no corta ni se introduce en la tierra con la prontitud y hondura que se quiere ó necesita profundizar: segunda, porque ni corta bien la raigambre de las yerbas, ni la labor se hace bien ni con la debida limpieza, pues blandeándose y poniendo roma trabaja más y peor el hombre: y tercera, porque una herramienta sin acero, si bien cuesta ménos, no dura ni la mitad que otra bien acondicionada con él. Por consecuencia es el más craso error suponer que ha de prestar el mismo servicio y tener igual duracion una con boca do acero, que sin él: por lo que, cuando el labrador note que por el uso la va quedando poco, debe llevar al momento la herramienta al herrero para que la calce, cuya operacion repetida oportunamente, hace que estên siempre en buen estado para el trabajo é íntegro el capital ó valor de ellas.

El azadon, propiamente dicho, es con bo- 
ca en la pala para cavar, tres veces más ancha que la que de ordinario ó comunmente tienen las espiochas, para cavar tambien, un poco más larga y más gruesa, bien acerada: y en el otro extremo, en que la dicha espiocha lleva pico, en lugar de éste una gruesa y estrecha boca de hacha, en direccion recta $y$ muy bien acerada para rudos cortes en las gordas raices del tronco de árboles, rajar palos y leña, cortar la gruesa raigambre de las cepas del arbolado y para otros varios usos semejantes. Dicha herramienta debe ser toda ella de una pieza de hierro dulce forjado en la fragua, y su hastíl de madera filamentosa algo retorcida naturalmente, para que no se rompa en los grandes esfuerzos que con la herramienta se hagan cavando, cortando, ó rajando. No sólo es utilísimo el azadon, sí que necesario á todo buen labrador para roturaciones, buenas cavas, desmontes, cortar y rajar leñas. Su peso, sin el hastil, no debe bajar de ocho libras.

La hoz debe ser grande, como de unos tres palmos de largo, de figura curva y ligeramente dentada en el corte, delgada la hoja y como pulgada y media de ancho é introducida en su manubrio ó mango de madera redondo, de unas seis pulgadas de largo ó poco más. Esta herramienta es muy útil y de poco coste, aprovechando mucho al cosechero de ta- 
baco para el roce de maleza baja en los desmontes; para cortar cógon y nipa para los techados de habitacion y camarines; para cortar y arreglar la saja con que se entercia el tabaco en rama: para segar las matas ó troncos de él y del maiz despues del corte ó recoleccion, y para otros varios usos.

Sobre la herramienta que llaman bolo los naturales de Filipinas, de la que usan y 1levan constantemente á la cintura los hombres $\mathrm{y}$ aún mujeres de campo, señaladamente en los pueblos cosecheros, necesario es convenir en la utilidad $\mathrm{y}$ aún necesidad del uso diario de dicha herramienta.

Respecto á la podadeia de que he hecho rérito, cuyo costo es insignificante y su utilidad mucha, consiste en una cuchilla pequeña de acero, como de unas cinco pulgadas de largo y una y media de ancho, algo curva hácia la punta y bien afilada, con su manguito ó empuñadura de madera ó cuerno. Esta herramienta de tan poco valor y fácil adquirir en las tiendas, ó que hagan los herreros, es de mucha utilidad y conveniencia al cosechero, pues con ella hará pronto y bien el corte del tabaco y de la semilla, el despunte de las matas y limpia de retoños sin resentirlas en sus tallos, troncos ni raices, como generalmente sucede haciéndolo con la fuerza á 
mano. Por ello, cuanto mejor temple y bien afilada tenga el labrador dicha podadera ó cuchilla, más adelantará en su trabajo con reconocida economia de tiempo y beneficio de las plantas.

El arado, si bien puede considerarse como una de las herramientas para la labor, no se incluve generalmente entre ellas y sí en los aperos de que voy á ocuparme.-El que usan los Cagayanes, si bien con alguna ligera modificacion, es semejante al de que se valen los labradores de las demás provincias de la isla de Luzon, segun pude observar; y no sólo la misma ruda construccion, si que tambien la manera inconveniente de llevar la besana, ó sea la direccion y cruza de los surcos de que me ocuparé al hablar del laboreo de los terrenos.

Mal de tanta importancia y trascendencia reclama un pronto y eficaz remedio ó modificacion en utilidad del progreso de la agricultura y mejoramiento del buen cultivo del tabaco, introduciendo en Filipinas arados idénticos á los que se usan en esta península. En tanto, pueden los cosecheros hacer construir, ó ellos mismos, los arados de que usan con más peso ó madera en el dental, que es la pieza en que ajusta el hierro que rompe la tierra, y darle más grueso y consistencia á la 
cabeza de la cama, que es la pieza de madera en que entra y ajusta dicho dental, con el fin de dar mayor impulso ó fuerza al arado para que entre bien el hierro ó reja en la tierra, rompa ésta y resulte buena labor. El hierro ó reja, tanto más gruesa y pesada, mucho mejor.

Ia mancera, que es la pieza de madera con que el hombre gobierna ó dirige el arado, y en la que apoya una ú otra mano, debe ser fuerte, hecha de un palo delgado y no de madera aserrada, como de unos cinco palmos ó más, colocada algo verticalmente en el mismo agujero de la cama, con un manubrio hácia atrás hecho en el palo mismo de la mancera.

No quiero ni debo hacer mérito, ni incluir entre las herramientas útiles, el diminuto pedazo de hierro clavado en un palito, al que llaman sacho en Filipinas, y con el que la holgazanería se entretiene allí.

Respecto á los aperos del arado, podría enseñarse en aquellas islas á los carabaos que tirasen con la cabeza, que es donde tienen la mayor fuerza los cuadrúpedos de su especie: modificacion fácil acostumbrándolos desde el principio, cuando son jóvenes. Para ello, podría hacerse un fiontal elaborado con burí ú otra materia téxtil, de que tanto abundan los bos- 
ques de aquellas islas, y de una dimension proporcionada que cubra toda la frente del ani. mal, sin taparle los ojos: el que se asegura de cuerno á cuerno en la base de ellos y ata con una larga cuerda dando rueltas por delante de dicho frontal y por detrás de las astas.

Para enlazar la camella que hoy les ponen al euello sobre el pecho, y entonces llevarian, más pequeña, por detrás de los cuernos, si bien no es fácil explicarlo escribiendo, y si propio de una escuela de agricultura, la práctica misma enseñaria el modo más sencillo y conveniente para su ejecucion y mayor duracion del apero. Entre estos voy á contar las carretas, carromatus, y cauas de que usan con bastante atraso los indígenas filipinos.

Digo atraso, por que su actual construccion es bastante ruda é inconveniente y en la que no se tiene en cuenta ni la ligereza del trasporte, ni las dimensiones, ni la duracion; pues las primeras podrian ser más útiles si se elaborasen con más discernimiento, ya que á los caballos se ba concedido en Filipinas el señalado privilegio de no servir para otra carga que llevar al hombre encima, regalos ó provisiones para los que explotan el país. Por lo que seria un adelanto graade para la agricultura filipina que se empezase allí á hacer uso 
general de las caballerías, tanto para el arado como para toda clase de carga, especialmente en las localidades doride se carece de caminos y puentes, que por cierto es lo más general. La prueba de que los caballos allí no sirven para otra cosa, tirar de un coche ó en hamaca llevar, entre dos de aquellos, á cualquier prógimo es, que no existirá en todas las islas un solo aparejo de carga; pues fuera de aquellos inconcebibles suplicios de madera en forma triangular á que los indígenas llaman sillas de montar, se valen de otro aparato de madera con cuatro puntas de las que á los lados cuelgan las árganas, ó parecida cosa á dos pequeños capachos, sin cinchos, pretal ni baticola, y atado de cualquier manera con bejuco ú otra cosa.-Consecuencias: si se anda cuesta arriba se sale uno ó la carga cae por detrás; si se marcha cuesta abajo, la carga se rá al cuello. y uno á las orejas del animal. Ya se pára, ya se ata, ya se vuelve á caer, ya otra vez á atar, á reanudar, sudar y á impacientarse, y se llega al punto donde vá, cuando se lleģa.

En ningun país del mundo hay más facilidad, posibilidad $y$ oportunidad para poder construir mejores, más cómodos, útiles y baratos, de grandísima duracion y conveniencia toda clase de monturas y aparejos para las caballerías, enseres para la agricultura y ar- 
tefactos. Aquellos bosques, aquellas márgenes de esteros y rios producen expontáneamente los más variados elementos ó primeras materias para todo lo necesario al hombre, sin que éste los utilice allí convenientemente como debiera y puede en su provecho y comodidad.

Por tanto, es una necesidad cada dia más apremiante el inculcar con la palabra, con el libro y con el ejemplo entre los labradores y cosecheros de Filipinas su amor al trabajo, principio seguro é inmutable de todo bien : y para que abandonen errores y prácticas inconvenientes, proporcionándose con la facilidad que puede el que quiere adelantar, para libertarse de la escasez y de las enfermedades á que son más expuestos los que se dedican al cultivo del tabaco, todas las herramicntas necesarias para el trabajo y todos los enseres útiles y aperos para los animales que le ayudan.

Podrá objetarse, que no existiendo en la Escuela de Agricultura de Manila museo de herramientas $\mathrm{y}$ aperos de los que se usan en esta península para el cultivo de la tierra y de las plantas, no es fácil á los herreros y carpinteros de aquella capital el construir unas y otros sin modelo á la vista: y mucho ménos en las poblaciones rurales del Archipielago.

Atendible es la objecion, y facilísimo y de 
poco gasto el medio de proveer á ella, enviándose oficialmente de aquí á dicha Escuela de Agricultura un ejemplar de cada una de las explicadas herramientas y aperos para que alli sirvan de modelo: y por la Direccion general de Colecciones, enviarse otros á cada una de ellas, y servirian de él en cada cabecera á los herreros y carpinteros de la misma, de los que copiarian los de los pueblos. Medio facilísimo $\mathrm{y}$ urgentemente necesario para generalizar en Filipinas los buenos aperos y herramientas para la agricultura.

\section{CAPITULO II.}

DE LOS ANIMALES PARA EL TRABAJO.

Creado el hombre por la sabiduría eterna, le impuso Dios la obligacion del trabajo auxiliándole con otros séres animados de que se valuria con la razon que no concedió á éstos: empero sirviéndose de ellos para su bienestar con discrecion y buen discernimiento. Por 10 que, cumple á su racionalidad emplear las fuerzas de los animales en ayuda de las suyas con prudencia y oportunidad, valiéndose de ellos de la manera más edecuada. 
El labrador precisamente es el que más necesidad tiene de ellos y sin los que no le es fácil ni posible ejecutar enteramente el cultivo de la tierra: por lo que, debe aprorecharse y servir de ellos con discreta prevision, cuidar bien de su salud y mantenimiento, dando el descanso necesario, sin que llegue á holgazanería, á aquellos cuadrúpedos destinados al trabajo. La distribucion prudente del tiempo para la fatiga, el descanso y la comida producen grandes ventajas, ya en la labor de la tierra, ya en la multiplicacion de la especie, ya en la conservacion del capital ó valor que representan los animales: sin olvidarse jamás de sus dolencias, ó enfermedades, siquiera agradecido á que le ayudan activamente y sufridos coadyuvan á proporcionarle bienestar, comodidad y aún placeres. En manera alguna se olvide de ello, pues dá indicios hasta de mal corazon quien castiga indebidamente, priva del sustento ó no alivia las dolencias de un sér que tambien lo creó Dios omnipotente.

En Filipinas, sólo un mal labrantin, un ocioso ú holgazan, puede tener flacos los animales para la labranza, con piojos y mal alimentados 6 mantenidos, pues la naturaleza es tan pródiga allí, que provée constantemente en todas las épocas del año; y sólo con un poco de cuidado ó prevision, y sin gasto al- 
gुuno, conserva el labrador en buen estado de salud y de fuerzas sus animales para el trabajo.-Pero si despues que se sirve de ellos las abandona ó ata sin darles alimento, ni los limpia y baña como debe hacer, se le enflaquecen y extenúan, no puede trabajar bien con ellos despues, enferman y aún suelen morir. ¿Y si semejantes descuidos y males proceden de estarse el labrador entretenido con el gallo, pasándole suavemente las manos i) distraido en la gallera? Entonces, entonces ya no merecen disculpa ni perdon tamañas faltas, que yo califico hasta de delitos.

Tan cierto es, que sólo basta ver en el campo ó en la casa de un labrador cualquier animal de los suyos destinado al trabajo, para saber, sin necesidad de preguntar ni inquirir, si su dueño es ó nó hombre laborioso y honrado, pues la presencia misma y buen estado de los animales convence de si Io es ó nó. El que siempre piensa en sus deberes $y$ en el trabajo no puede ménos de ser honrado, pues siendo laborioso y trabajador, ni peca ni delinque y Dios le ayuda visiblemente en todo. ¿Qué sería de los malos labradores de allí, si tuvieran que trabajar con meses de anticipacion y de un año para otro laborear sus tierras en cantidad proporcionada, sembrarlas y cultivar el alimento para los animales, y hacer 
con todo cuidado y prevision el acopio de aquél, como tienen que hacer los de aquí?Nunca podrán los labradores filipinos agradecer bastante á la providencia de Dios $\in 1$ especial beneficio que disfrutan.

Tres son las especies de animales que en Filipinas se pueden emplear con utilidad para la labranza de la tierra y cultivo de las plantas: el carabao ó búfalo, el vacuno, y el caballar, pues no hay mulos ni asnos. Respecto al primero, que es el único de que se valen en aquellas islas para dicho objeto, aún prestaría mejor servicio si se les acostumbrara á tirar. del arado con la cabeza, como he dicho en el capitulo anterior.

Que tienen más fuerza en ella es evidente y por ello se puede asentar más el arado y hacer buena labor. Tirando con la cabeza, como la llevan sujeta, no se distraen con las moscas ni se entretienen para coger al paso alguna yerba ú otra cosa que rumiar: por consecuencia, yendo mejor gobernados, los surcos salen más rectos y en la besana no quedan claros sin labrar la tierra. Estas ventajas son incuestionables ante la experiencia práctica.

El carabao es un excelente animal para $\in 1$ trabajo, no siéndolo hoy tanto por el poco cuidado y ligero alimento con que se les mantiene. Si se quiere que los animales trabajen 
bien, necesario es tener cuidado con su buena alimentacion, baños y descanso regular en medio del dia.

Las vacas y bueyes, de los que no se hace uso en Filipinas para el trabajo, es un descuido muy notable: pues si bien es cierto que son de ménos corpulencia que el carabao, no por ello dejan de ser unas y otros más útiles para el tiro y la labor de las tierras. Ninguna dificultad ofrece aparear dos vacas ó bueyes y hacer que aren mejor que los carabaos, por ser su paso más ligero: y como el laboreo de las tierras para el cultivo del tabaco no se ejecuta sinó cuando están en sazon, seria un adelanto para los progresos de la agricultura y supliria con ventaja la falta de carabaos.

Dícese alli, que no pueden aguantar mucho el trabajo y ménos asi que calienta el sol. Yo he observado no ser tan exacto, pues el hombre, cuya organizacion es muchísimo más delicada, trabaja si quiere á cualquier hora del dia, sea la que fuere. Lo cierto sí, como he dicho antes, que en estando el carabao bien mantenido, dándole sus baños y descanso proporcionado, puede trabajar doble tiempo del que hoy se emplea 'en las labores del campo. ¿Cómo es que trabajan á cualquiera hora del dia en los arrastres y acarreos dentro de Manila y sus arrabales y sc conservan gordos y 
en buen estado? Para ir á una romería ó fiesta de otro pueblo á divertirse ¿no les hacen tirar de la carromata llena de personas, aunque sea al medio dia? ¿Pues por qué no trabajar más en la labor?

Tambien podria aprovechar mucho su enseñanza para la reforma del mal arado de que se viene haciendo uso en Filipinas; al que se puede empalmar, de quita y pon, un palo largo á manera de la lanza en los coches, llamado engero, y el que su punta extrema se aposa y sujeta en la camella: que no es otra cosa que un palo plano como de vara y media largo ó poco más, en que se labran al canto de ambas extremidades dos semicírculos para que asiente en la parte superior del cuello de los animales, por detrás de los cuernos y se ata con una cuerda en cada uno á raiz de las astas cogiendo por delante el frontal.

En el caso de ensayarse, para introducir la utilísima reforma del arado, á dos vacas 0 novillos se les enseña á que aren juntos y apareados en los términos que dejo explicado: en cuyo caso no debe llevar entonces el arado el gancho fijo de hierro en la punta superior de la cama, al que los filipinos llaman calauit, pues que unidoá la misma vá el engero ó timon del arado, sujeto con las biiortas, ó sean dos grandes anillas de hierro quejuntan una y otro. 
La besana ó direccion de los surcos debe llevarse á lo largo yendo y viniendo, y no dando vueltas en cuadro por dentro: de cuya manera se adelanta poco en el trabajo y hace mala labor.-Los laóradores de Bataan y de Cagayán pudieron ver mis lecciones prácticas que sobre ello les dí, á los unos para el cultivo de la caña dulce y el añil, y á los otros para el del tabaco y maiz, cuyo general convencimiento práctico necesitaba más tiempo del que mandé dichas provincias.

Por lo que hace al ganado caballar, grande ventaja reportarian los labradores filipinos con enseñarlo al trabajo del arado, especialmente los cosecheros de tabaco en atencion á la mayor inteligencia instintiva de los caballos, señaladamente para las operaciones agrarias que requieren prontitud y más cuidado, unciendo dos de ellos apareados por el mismo sistema que llevo dicho respecto al vacuno: empero con la diferencia de que el tiro debe ser con el tronco del cuello y no con 1a caleza, por medio del ubio, en lugar de camella.

Consiste dicho apero en un palo medianamente grueso y redondo de igual longitud que la camella, en figura algo curra en el centro y la que queda hácia abajo y en ambos extremos otra en órden inverso, cuyas curvaturas proporcionan buen asiento sobre el cue- 
110 de los animales. En ambas curvaturas y por medio de agujeros abiertos, en ellos se fijan dos palos labrados como de tres palmos de longitud y se revisten con tela grosera ó con cualquiera otra materia téxtil para proporcionar alguna blandura, y con el fin de que no hieran con el roce la piel del animal y trabaje con desahogo. En el centro de la curva hácia abajo se fijan los barzones, ó sea unas cuantas rueltas juntas de cuerda gruesa formando un anillo, del diámetro del palo del engero ó timon, para meter éste, en el que habrá, uno ó más agujeros en su punta para introducir, de quita y pon, la alavija; que es un delgado hierro redondo, como una cuarta de largo, puesto por delante de los barzones y en ellos se sujeta el tiro del arado.

El modo le asegurar el ubio en el cuello de los caballos, consiste en una atadura con cuerda por los extremos inferiores de carla dos palos de los que hácia abajo entran en el cuello del animal. La experiencia práctica enseñará lo que no es fácil explicar con la pluma. 


\section{CAPITULO III.}

DE LA ROTURACION DE LOS BOSQUES.

Dilatada superficie de las islas Filipinas, cuva extension se ignora, cubierta es por bosques seculares tan antiguos como el Archipiélago y en los que la planta humana europea no pisó quizá. Vírgenes aún en su mayor parte $y$ formadas por una vejetacion admirable que atestigua el poder de Dios y las infinitas maravillas de su creacion, sorprendido y humillado penetra el hombre por ellos con recoyimiento espiritual, confesando su pequeİez y la omnipotencia del Sér Supremo.-Nida más grande y encantador, nada más sorprendente, nada más delicioso que aquella creacion vírgen y los caprichos tan inimitables como fantásticos de la naturaleza en las manos aún de su creador. Engalanados con su perenne follaje, matizados con tan innumerables como variados colores, embellecidos con sus flores caprichosas, embalsamadas sus auras por el conjunto arrobador de fragantes perfúmes y cruzados por caudalosos y pequeños rios, olvídase el hombre allí de lo pasado y 
apenas acierta si no á gozar.-Me es imposible decir las inefables sensaciones que experimenté en mis largas travesías y estancia en ellos.

Empero como no sea dado á la humanidad que permanezca enteramente la haz de la tierra en tal estado, por necesitar el hombre la porcion de superficie que le es necesaria para su existencia material, por ello entra en los bosques, tala y rotura.-Para ejecutarlo con utilidad y economía conviene hacer el desmonte del arbolado de la manera que explicaré.

Es costumbre general en Filipinas rozar primero con el bolo los bejucos, cañas y demás maleza que vejeta entre el arbolado pegándole fuego despues que la ven seca. Arde y desaparece quedando chamuscados unos y ardiendo otros árboles, á los que á su tronco arriman más combustible para que caigan. Entonces empiezan á recoger las ramas esparcidas que no consumió primero, y haciéndolas montones se lo vuelven á dar; y de este modo hacen desaparecer la maleza y árboles pequeños. Despues, continúan alimentando el fuego sobre los grandes troncos caidos y arrimando leña al tronco de los que quedan de pié hasta quemai la mayor parte do ellos; y sin acabar de arder los grandes troncos, ni desceparlos, ni otro trabajo alguno, siembran á golpe en los claros 
el arroz con la punta de un palo y las matas del tabaco.

Natural y consiguiente es que en el primer año produzcan escelente fruto unas tierras tan potentes, vírgenes y beneficiadas con el fuego y la ceniza que hizo la quema. Pero como el fuego, si bien violento fué pasajero, luego que vienen las primelas lluvias vuelve á desarrollarse una nueva vejetacion y á repoblarse la maleza, creciendo á la vez los retonos de los troncos del antiguo arbolado. La vejetacion no pára y en proporcion que más crece más sombra dá á sus troncos y más se desarrolla. Al siguiente año son ménos los claros para sembrar; y al tercero alguno apenas: entonces, abandonan aquél terreno y á otra parte á comenzar el mismo perjudicial sistema de desmonte y siembra.

El resultado de tamaños errores é imprevision es, que rayan quedando yermas dilatadas superficies no lejanas de poblacion, privándose á si mismos y á los venideros de leñas, bejuco, cañas, y madera útil para diferentes usos y la construccion de puentes, tulays, bantayanes, camarines y casas: y más en un país donde son diariamente expuestas las poblaciones á los frecuentes incendios, tempestades y huracanes desoladores que acontecen.

Yo convengo en la necesidad de la quema 
para el desmonte de unos bosques seculares cuya muy tupida maleza á bastantes varas de altura desde la tierra y entretegida al espeso colosal arbolado por diferentes vejetales trepadores, y otros que rastrean á muchas brazas ce longitud, su desmonte á brazo seria interminable y costosísimo: pero no se me podrá negar, que si el actual sistema economiza, tambien es muy perjudicial por la carencia reglamentaria para los desmontes, pues cada cual pega fuego al bosque donde le parece ó quiere sin responsabilidad alguna ni tener en cuenta las consecuencias.

Con efecto, ocurre con frecuencia el no pensarse más que hacer qucnia si no de un pequeño bosque, y prendido el fuego á éste sigue ardiendo á merced del viento dias y semanas dejando yerma dilatada extension de terreno. De tamaña imprevision inmemorial resultan esas grandes llanuras y montes sin un solo arbusto donde guarecerse el hombre ni los animales útiles, de los abrasadores rayos del sol, la creciente dificultad y carestía de maderas para construccion de casas y demás necesidades rústicas en no pocas localidades de aquellas islas.

No desconozco, por experiencia, ser una necesidad tambien en Filipinas los grandes desmontes para mejorar las condiciones higiéni- 
cas de las poblaciones que sitúan en terrenos bajos y pantanosos, ó circunvaladas de grandes bosques: por que la espesura de ellos hace mucho mas húmeda la húmeda atmósfera de aquellas islas, atraen las lluvias con más frecuencia, suelen enrarecer el aire é impiden la ventilacion; y que son tambien orígen ó concausa para el acumulamiento de aquellas espesísimas blancas nieblas, que adheridas á la tierra, tan peligrosamente nocivas son á la salud del hombre á la otra parte de los Caraballos en la provincia de Cagàán, por más útiles que sean $y$ son para el cultivo del tabaco.-Por lo que, y otras razones que omito, son necesarios y convenientes los desmontes en aquel Archipiélago: pero ejecutados con discernimiento y prevision.

Para hacer bien un desmonte y roturar en un bosque, despues de elegido el terreno ó sitio se observará primero la clase de árboles útiles que hay parala construccion y necesidades de la labor: y dejando viva alrededor de ellos toda la maleza que haya á diez ó doce brazas de distancia se cortará en los claros la demás, pegándola fuego despues cuando esté seca. La maleza viva resguardará bastante á los árboles elegidos, $\mathrm{y}$ cuando se haya acabado de quemar toda en los claros, entonces con el hacha y el bolo se vá cortanảo la que quedó alrededor de 
los árboles escogidos, y separándola de ellos se hace montones en los claros en donde se quemará, y toda la ceniza con espuertas ó bilaos se extiende con igualdad en el terreno. Por este medio, aunque más trabajo, conseguirá el labrador conservar en las nuevas roturaciones los árboles útiles que haya dejido vivos, de los que con ventaja se aprovechará despues recompensándole el mayor costo que hizo para el desmonte y roturacion.

Despues de haber hecho desaparecer enteramente por dicho medio todos los palos, ramas, troncos, cepas y raices superficiales, se procederá á sacar unas y otras con el azadon hasta una profundidad conveniente, para que el arado no encuentre despues tropiezos en la roturacion y labores sucesivas. Con las cepas hará 10 mismo, practicando alrededor de ellas con el azadon una buena zanja, y ya con el hacha ó con fuego las hará desaparecer enteramente. Despues, con la azada rellenará el hoyo con la misma tierra que sacó al hacerlo y la de alrededor, hasta dejar llano é igual el terreno.

Fn esta situacion yá, por medio del azadon se quitarán los resaltos pequeños esparciendo la tierra á los lados bajos. Si los resaltos son los montones cónicos de tierra que levanta el anay por debajo, se les pondrá leña 
encima, y dará fuego vivo y continuado para que tostándose bien la tierra mueran tan perjudicialisimos gusanitos. Despues, á la primera lluvia se deshacen dichos montones con el azadon, y en parando de llover, fuego encima otra vez hasta que muera todo el anay.

si el terreno que se vá á roturar situase á la márgen de algun rio ó estero y sus orillas fuesen falsas, ó tan bajas que desnivelen aquél, antes de quemar los árboles y maleza del bosque se cortarán buenas estacas para sujetar con ellas dichas orillas, en las que á golpe se clavarán para resguardar el campo de las grandes avenidas: precaucion que no debe olvidarse reponiendo las estacas que se pudran, para no ser expuestos á lo que los labradores abandonados; que cuando están más descuidados una avenida les inunda la sementera, se lleva parte del terreno con el fruto ó se le inutiliza con las arenas, piedras y cascote. El resguardo do las lindes y orillas de un campo es de más importancia de la que puedan creer los malos labradores.

Ejecutado cuanto acabo de decir, se esperan las primeras lluvias, y cuando se vé que el terreno se ha remojado y está en sazon se mete el arado y dá una labor tan profunda cuanto permita la tierra y accidentes del terreno. Despues de esta primera labor se dá otra cru- 


\section{5}

zando los surcos: es decir, que si la primera fué de Norte á Sud la segunda será de Oriente á Poniente.

Con este primer laboreo aparecen varias raices; las que por medio del azadon se ván descubriendo, desenterrando y arrancando hasta que no quede alguna, ejecutando lo mismo en todas las labores sucesivas para que quede bien limpio el terreno. Despues, si vue1ve á llover, cuando está la tierra en sazon, se mete otra vez el arado y dá una buena labor cruzando las surcos de la última; esto es, de Sudoeste á Nordeste, con lo que se vá rompiendo por bajo el terreno con igualdad.

Tanto en esta segunda labor como en la primera, con el azadon se romperán y cabarán bien los huecos ó rincones que no haya podido coger el arado, cuşa operacion, además de ganarse con ella más superficie para sembrar, evita que las malas yerbas crezcan, semillen é invadan progresivamente el terreno, como sucede en las tierras ó campo de los malos labradores. La limpieza de las tierras en toda la extension labrable es de bastante conveniencia y utilidad, por las razones que acabo de decir, y otras que fácilmente se deducen. Preparado el terreno en los términos referidos. resta solo nivelar cuanto sea posible aquellos que estén pendientes ó inclinados, y aún los 
llanos que tengan desigualdades, cuya explieacion es objeto del capítulo siguiente.

Insistiendo sobre la utilidad de esta operacion que, no solo facilita la igualdad para los riegos de pié, sí que tambien más conveniencia para hacer las siembras del arroz, del maiz y el trasplante de las matas del tabaco.

\section{CAPITULO IV.}

DE LA NIVELACION Y DESECACION DE LOS TERRENOS.

La igualdad de superficie en las tierras de labor es tan conveniente como útil, pues economiza jornales en el laboreo, se gana tiempo en las operaciones, proporciona que los frutos sean mejores y conserva las cualidades propias del terreno, evitando tambien los deterioros naturales ó accidentales que en el mismo causan las tempestades y huracanes.

Estas buenas condiciones, útiles á toda clase de sementeras y frutos, son de másimportancia en los terrenos dedicados al cultivo del tabaco.

Sabido es por la experiencia que los terrenos 
pendientes ó inclinados, tanto cuanto más lo sean ó estén, mayores son las dificultades para el laboreo de ellos y los frutos que producen generalmente no son los mejores.

Con efecto, en un terreno inclinado no pueden las plantas disfrutar de los beneficios a tmosféricos de igual modo que las que se crian en tierras llanas que, además de conservar to. das sus propiedades caracteristicas, reciben por igual el sol, el aire y la lluvia; cuyas tres circunstancias son muy de tener en cuenta para las que se dedican al cultivo del tabaco.

En un plano horizontal, desde que aparece el sol describiendo vá su círculo ascensional, progresiva y exactamente calienta las plantas $\checkmark$ las beneficia por igual hasta que desaparece. El aire, tanto en tiempo regular como en el que no lo es, lo reciben con igualdad tambien y por entre ellas pasa con más beneficio y ménos daño. La lluvia, sea regular ó tempestuosa, aprovecha más y no causa perjuicios; con la muy atendible diferencia, de que las lluvias fuertes ó tempestuosas causan muchos en los terrenos pendientes, pues arrastran de lo alto á lo más bajo la superficie en labor dejando las plantas descubiertas en la raiz ó caidas en tierra. Además, progresivamente con las lluvias, tempestades y riegos, las tierras se van corriendo á la parte inferior arrastradas por la 
accion de las aguas, se llevan toda la flor de tierra útil para el cultivo y si bien se van beneficiando las partes más bajas, quedan las del terreno alto sin elementos útiles para la vejetacion.

Además de esto, el laboreo de ellas con el arado ofrece tambien más dificultades y trabajo para el hombre y para los animales que en los llanos, en donde cunde más y el tiempo se aprovecha con ventaja. Más aún; para el cultivo de las plantas y corte del tabaco ofrecen más facilidad y conveniencia las tierras llanas, pues se labran mejor y cosecha con más esmero.

Si despues de roturado un terreno quedasen algunos desniveles en él, en los puntos que más resalten se procede al rebajo dae la siguiente manera. Despues de una lluvia que remoje bien la tierra se mete el arado y trabaja con él en las partes más altas que convenga rebajar. Removida la primer capa de tierra, por medio de un cajon fuerte de madera de la misma hechura que un medio cabán, pero cortados ambos lados á lo largo de mayor á menor, en éste se colocará una boca de hierro bien acerada; en los lados, una asa fuerte, á las que se atan dos tirantes de cuerda que van al cuello ó cabeza del carabao para que tire: y en la parte posterior del cajon una mancera 
fija, que sirve para apretar hácia abajo para cojer la tierra removida antes; y tirando del cajon el animal se lleva á las partes bajas, y vuelve otra vez ácargarse con aquella yá llevar á los sitios bajos hasta conseguir el rebajo de las partes altas. En tanto, no pára el arado de remover la tierra que se quiere ó necesita rebajar, ayudando tambien esta faena con el azadon: y por este medio repetido se consigue allanar en lo posible los terrenos.

No obstante lo dicho, el mejor método para nivelar las partes desiguales 6 más elevadas del terreno, con el fin de trasportar la tierra á las más bajas ú hoyos accidentales, se ejecutará con el azadon cavando por igual los resaltos hasta que desaparezcan y toda la superficie quede igual.

Para nivelar las orillas bajas de los terrenos que sitúan cerca de esteros ó rios, ya dije en el capítulo anterior, que las estacadas servian no sólo para resguardarlas de las avenidas, sí que tambien para que no se derritan ó vacíen, contribuyendo mucho á la nivelacion de las tierras. Por tanto, repito, que el cuidado de las estacadas no debe abandonarse, si el terreno ú otros accidentes de localidad no permiten la plantacion de árboles que aseguren con sus raices dichas orillas y las defiendan de la constante accion de las aguas. 
No hay terreno malo ni accidentes insuperables á la voluntad decidida y perseverante del hombre, y más en Filipinas en donde hay tanta variedad de buenos materiales para el resguardo de las orillas de los terrenos. Lo que falta es aquella voluntad y aquella perseverancia, en donde cada cual coge ó toma la porcion de tierras que le parece $\delta$ quiere, sin gasto alguno, ni necesidad de licencia 6 permiso prévio, cuya omnímoda libertad es la causa primaria del atraso grande de la agricultura filipina.

Voy á ocuparme ahora del modo de practicar la desecacion de los terrenos excesivamente húmedos por infiltraciones $\mathrm{y}$ de los pantanosos.

Cuando en un sitio ó punto del terreno hay constante humedad ó sudaderos de agua, se observará si procede de infiltraciones superiores; esto es, si por algun lado hay en tierras más altas alguna fuente ó manantial sin salida. En tal caso se abre una zanja ó acequia que reciba las aguas $\searrow$ lleve por el sitio que convenga alejar su desagüe, cuya profundidad y anchura será la conveniente para el fin que se hace.

Si proceden las infiltraciones de alguna acequia ó cauce de riego ó desagüe que haya en la parte más elevada del terreno, se regis- 
tra el cauce con el objeto de saber el punto ó sitio por donde se producen las infiltraciones: si el terreno es por allí más franco, conviene asegurar la caja de la acequia con hormigon de cal y arena bien trabado y puesto en seco; es decir, que el agua no haya pasado en bastantes dias antes de ejecutarlo.

Si el sudadero es producido por agujeros ú horadaciones que hacen algunos animales cuyo abrigo y estancia tienen bajo de tierra, en este caso tan sencillo al parecer evitar, hay que perder no pocos dias y tiempo hasta saber fijamente el punto principal de entrada á la madriguera, que de ordinario son más de uno los agujeros; medio de que se valen para su comodidad y defensa. Descubierto el punto de más frecuente entrada y salida, allí se les ataca por medio de lazus y otras trampas de cetrería si son topos ó ratas.

Si los agujeros ú horadaciones son de grillos cebolleros, animal tan pequeño como dañino, y tan astuto como ágil para ocultarse bajo de tierra, cuyas madrigueras suelen profundizar hasta media vara y aun más, con varias comunicaciones subterráneas en distintas direcciones, no debe perderse el tiempo en acecharlos para cojer fuera de tierra, porque es cuasi imposible: por lo que practicará una escavacion minuciosa y profunda hasta encontrar el ani- 
malito en los últimos rincones, y matará. Despues volverá á arreglarse bien la parte de cauce en que se hizo la escavacion apisonando bien la tierra; que luego que se entarquine con el fango quedará asegurado el terreno.

Los de mucha humedad por destilaciones ó sudaderos grandes, por rebalses de aguas sin corriente, ror estancamiento de las lluvias, ó por otros accidentes y causas perennes que los hacen pantanosos, pueden desecarse por medio de grandes sangrías en el terreno, abriendo zanjas tan anchas y profundas cual convenga para la fácil salida de las aguas detenidas en la direccion más á propósito para el desagiue. Por este medio consigue el labrador poder cultivar aquella porcion, chica ó grande, de terreno perdido y evitar las pútridas emanaciones que se desprenden, tan nocivas y perjudiciales al hombre como enfermas para la salud de sus animales.

Si las destilaciones ó rebalses proceden del terreno superior ó más elevado, se practicará la sangría á la cabeza de la labor por bajo de aquél, sin perjuicio de hacer otra ú otras donde convenga. Y dicho sea de paso, podria formarse al final del cauce de la sangría una anchura para bañar en ella los carabaos á las horas de descanso; para cuyo fin y el de sacar otra utilidad, se sembrarán alrededor algunos 
plátanos que den sombra, fruto y saja para el enterciado del tabaco. Lo mismo puede hacerse en las orillas del cauce de las sangrías ó zanjas de desagüe, y las raices asegurarán tambien las orillas.

Cuando el labrador es discreto y previsor, adelanta mucho en todas las faenas del campo, mejora sus terrenos, los hace más productivos, llega á trabajar ménos adelantando más, el hambre no se acerca á sus puertas y teniendo además de lo necesario para la vida material, se proporciona otras comodidades y honestos placeres, de todo lo que carece el ocioso, el holgazan $\delta$ mal labrador.

Entiéndase, que yo no tengo por honesto placer el ruinoso vicio de la gallera, orígen de la pobreza de muchas personas que lo tienen de jugar con los gallos y hacer puestas. - ¡Decidme, filipinos, si no es cierto que más de un padre hasta entrega á su hija en servidumbre por dinero que pide, por carecer de él, para ir á jugar en la gallera! ¿No es más divertido el pasatiempo, en dias festivos, de bailar un lícito cundiman ó alegre fandango y cantar honestas canciones? 


\section{CAPI'TULO V.}

DEL LABOREO Y ABONO DE LAS TIERRAS.

La preparacion de las tierras para sembrar ó trasplantar en ellas los frutos que el hombre se propone cultivar, es lo primero que debe hacerse con la prevision que aconseja la ciencia y la experta práctica.

Es innegable que la mala preparacion del terreno dá fatales consecuencias al labrador, el que coje con abundancia buenos frutos si las laborea bien $J$ oportunamente: por lo que, importa mucho al cosechero trabajar cuanto pueda las tierras que destina al cultivo del tabaco, á cuya planta no se engaña con malas labores, porque se burla á su tiempo del mal labrador.

Las labores para el cultivo del tabaco serán de cuatro clases: barbechos, cavas, binas, y escardas. La primera consiste en la preparacion de ellas por medio del arado, con diferentes objetos si todos á un mismo fin: el de sembrar ó plantar para cultivar bien los frutos. 
Las tierras que no se abonan con estiércol se deben dejar en descanso uno y dos años, para que durante este tiempo reciban el beneficio atmosférico y se repongan con él de lo que perdieron con el fruto anterior; en cuyo espacio y para que mejor tomen aquél se las barbecha ó labra con el arado dos ó mas veces cada año cuando las yerbas son pequeñas y antes que florezcan, con el fin de matarlas antes que germine la semilla, por cuyo medio y con perseverancia se logra ver las tierras limpias enteramente.

No podré encarecer bastante la importancia de que las tierras dedicadas á toda clase de cultivos, especialmente al del tabaco, estén lo más limpias posible. Debo detenerme algo sobre este particular para convencer á los labradores filipinos del error perjudicialísimo en que generalmente vienen sobre la falta de limpieza en sus tierras de labor.

Nótase en ellas generalmente encontrarse plagadas de toda clase de malas yerbas, dominando la juncia y la grama cual en praderas incultas: ¡la juncia y la grama! ó sean las dos más malas yerbas que existen contra los afanes del labrador. Nada más malo ni peor: son su pesadilla y enemigos constantes y al que roban el producto de sus afanes. No hay palabras bastantes para decir todo el mal que 
causan en la labor, ni para recomendar toda clase de trabajo y fatigas hasta conseguir su desaparicion de las tierras en cultivo.

Ya he dicho cuál es el objeto de barbechar las tierras; por lo que, repito, que cuantas más veces se aren antes de sembrarlas, mejor resultado dará el fruto en calidad, bondad y cantidad y, por consecuencia, mayor la utilidad que tendrá el buen labrador.

Los cosecheros de tabaco harán el primer barbecho despues del segundo ó tercer corte de aquél rozando antes con la hoz todas las matas, y haciéndolas montones las pegará fuego para que mueran las larvas y ovaciones de los gusanos metidas en los secos y articulaciones de aquellas, y para que no sirvan tampoco de alimento ni de abrigo á ninguna clase de insectos. Lo mismo harán con las cañas del maiz, pues es un error el creer lo contrario. Por consecuencia, uno de los más eficaces medios para extinguir de un terreno las diferentes clases de gusano, que tan irreparables perjuicios causan en los tabacales, es la quema anual de todas las matas de tabaco y cañas del maiz, despues de la recoleccion.

Acostúmbrase desacertadamente en Filipinas y con el más evidente perjuicio de los mismos cosecheros, sembrar de maiz las mismas tierras que acaban de llevar tabaco sin 
ningun descanso, estercolado ni barbechos. Las consecuencias son bien palpables, pues ni cojen buen tabaco ni buen maiz. Pero hay más, que es sembrarlo tan espeso como el arcarcél ó verde que se cria en Europa para forrajear las caballerías; con la añadidura, de no arrancar despues ni una sola mata aunque contenga cada golpe cincoó seis cañas de maiz. -Esto parecerá increible á los buenos y entendidos labradores $\mathrm{y}$, sin embargo, es una notoria realidad allí del error gravísimo en que vienen y sobre lo que he podido observar no hubo interésalguno en convencerles y hacer abandonar tan perjudicial sistema.

Yo diré á los cosecheros de tabaco de aquellas islas, que uno de los frutos que más esquilman la tierra es el maiz: que, además de llevarse el abono artificial ó natural que tenga el terreno, lo deja descalzo; y si es de riego, enteramente esquilmado y descalzo para poder llevar despues el más ligero fruto, sin que antes se le beneficie con barbechos y descanso ó con abonos de estiércol. Creer lo contrario es el más supino error en agricultura, igualmente que dejar en cada golpe inás de una caña de maiz.

Los dos primeros barbechos para el tabaco se ejecutarán despues de alguna lluvia y cuando la tierra está en sazon, practicando el se- 
gundo en direccion contraria al primero; es decir, cruzando los surcos lo más hondo posible y bien yunta la labor, con el fin de que se suelte la tierra, voltée la de abajo arriba para que la beneficien los elementos atmosféricos. Cuanto más se barbechen las tierras, mucho mejor; pues á su tiempo, repito, el fruto recompensa con usura al buen labrador. Por tanto, mientras no tenga necesidad el cosechero de ocuparse en otras urgentes faenas, no debe estar ni una sola hora del dia ocioso, sí que con su carabao dando labor á sus barbechos para tabacales. - Tanto vale estar trabajando con el arado como ganando dinero.

Bien preparadas las tierras sólo esperan la época oportuna del trasplante, y en la que se vuelve á dar otra buena y concienzuda labor de arado: á seguida se tablea el terreno con el fin de desmenuzar todos los terrones grandes que haya y con el de que la tierra guarde por debajo el jugo y frescura que tenga.

El tableode las tierras aradas se hace con una gruesa tabla de unas dos brazas ó poco más de largo y ancho de media vara, con dos fuertes anillas de hierro clavadas en el canto, á las que se atan dos cuerdas para que tire el carabao ú otro animal de fuerza. Sobre la tabla se sube el hombre piés derecho, $\nabla$ no en cucliyas ni sentado, quien dirige al animal y vá y viene 
á lo largo hasta dejar la tierra llana. En esta situacion yá sólo espera el dia del trasplante.

La cava es una operacion poco ó nada acostumbrada en Filipinas siendo, como es, la más útil para el cultivo de las tierras, pues con ella se consigue lo que no puede hacerse con el arado; esto es, cortarla por igual, voltear mejor la de abajo arriba, profundizar cuanto se quiere la labor $\mathrm{v}$ beneficiar perfectamente la tierra. Cierto que es más costosa que la del arado; pero no lo es ménos que tiene grandes ventajas en todo y para todo. No digo, que los naturales poco ó nada acostumbrados al trabajo de las brenas cavas con el azadon, se valgan exclusivamente de él para la preparacion y laboreo de las tierras para el tabaco; pero sí que es necesario en muchos casos, especialmente para las roturaciones y cava de los cornijales que deja el arado, y para otros muchos utilísimos usos. Cuando hable del cultivo del tabaco diré lo conveniente sobre el uso de la azada.

La bina no es otra cosa que la segunda cava que se dá, algo más ligera, para matar la yerba y aporcar las plantas.

La escarcla es de dos maneras: una, que se hace á mano arrancando todas las yerbas; y la otra con escarclillo ó almocafre, rayendo la corteza de la tierra despues del trasplante y 
cuando ya están con cuatro ó cinco hojas nuevas las matas de tabaco. El objeto de esta primera labor es romper la corteza de la tierra, labrarla ligeramente, soltar las plantitas de la presion circular del terreno, especialmente si se hubiesen regado á mano en el acto del trasplante, ó caido lluria despues, y matar las Jerbas.

A lo explicado anteriormente, no con la extension de lecciones completas de agricultura práctica, se reduce el prinsipal laboreo de las fierras: habiéndome reservado para este lugar el anatema que merece un inútil pedacillo de hierro clavado en un palito, de uso general en Filipinas, llamado sacho, de que hice mérito en el capítulo primero de esta seccion, símbolo de la holgazanería, de la flojera, de la inercia $\mathrm{y}$ de la ignorancia.

Las tier'ras se benefician ó abonan, como llevo dicho, por medio del laboreo y barbechos, del descanso, de los estiércoles, de las quemas y de las inundaciones.-Respecto al vacío ó descanso de un año ó más, poco tengo que añadir á lo dicho sobre ello: al descanso, ó sea no sembrarlas, debe unirse el darlas barbecho, porque si no, repito, crecen y semillan las yerbas, se plaga el terreno y convierte en un erial; lo que debe evitarse á tnda costa, pues roban la sustancia que necesitan las 
plantas útiles $\Gamma$ luego cuesta inás trabajo en prepararlas otra vez para sembrar.

El medio más pronto y útil es el abono con estiércoles, del que, con asombro inconcebible, no se hace uso en Filipinas. ¿Podrá creer ningun europeo, si no lo vé con sus ojos, que alli no se guarde el estiércol ó basura de las casas, cuadras y corrales, y que se queme en medio de las calles con tan grande perjuicio de la agricultura? Pues nada más cierto: diariamente le suelen dar fuego los vecinos 1lenando de humo las calles y apestando las poblaciones. En la capital misma, en Manila y suburbios asi se hace ó sirve para rellenar los hoyos ó desniveles del piso de las calles y plazas, cuya diaria limpieza produciria bastantes carros de basura. Repito, que sólo viéndose puede creer, y el grande atraso de la agricultura en Filipinas.

Yo recomiendo mucho á los cosecheros de tabaco filipinos que reunan en los cercos de sus solares cuanta basura puedan para abonar las tierras, seguros de que el estiércol es oro para el labrador y como tal, ir reuniendo y guardando, seguros repito, de que con él verán producir sus tierras abundantísimos y buenos frutos.

Conviene advertir, que el excremento del ganado racuno y de los carabaos es frio y de 
malas condiciones por sí solo. Con efecto, son tan insustanciales las partes inorgánicas de que se compone, que apenas se notan elementos de nutricion para la vida de las plantas; y lo peor es, que las semillas secas ó bien en sazon de las yerbas que al comer ingestan en el vientre, no las mastican por carencia de muelas ni las descompone la diges tion, cuyas semillas, despues de espelidas, se reproducen en la tierra, como la experiencia tiene acreditudo y yo convencido por una lar. ga observacion. Por lo que, no debe darse de comer al ganado racuno que trabaja en la labor yerba dura que tenga bien cuajada la seliilla, porque si el excremento se lleva despues á la tierra, en lugar de beneficiarla es un perjuicio, pues toda aquella nace ó se reproduce ensuciando ]os terrenos. Por tanto, debe revolverse con otras buenas basuras y recortarse con la azada ó mano de hierro para que apilado fermente bien, se combine y mueran las semillas.

La manera de abonar las tierras con él, es cuando esté bien fermentado; y en la última labor preparatoria para el trasplante se lleva á la tierra, reparte en montones iguales, y con igualdad se extiende despues sobre toda ella: metiendo en seguida el arado con el fin de enterrarlo y revolver; se tablea el terreno 
despues y hace el trasplante con el intervalo que permita el estado del semillero. si la cantidad de estiércol no fuese bastante para cubrir toda la superficie del terreno, se aprovechará del modo siguiente.

Despues de hecho el trasplante y cuando las matas de tabaco estén ya seguras y creciendo con tres ó cuatro hojas nuevas, se lleva el estiércol á la sementera, se reparte en montones para mayor comodidad, y al tiempo de dar la primera escarda se echa á mano un poco alrededor del tronco de cada mata, pero sin que toque á ella, y entierra con el escardillo ó almocafre con el fin de que abone la planta y la dé vigor para su crecimiento, desarrollo y calidad. El cosechero que esto haga verá despues con suma alegría crecer bien sus tabaçles y obtendrá seguramente mejor fruto y cosecha. Sólo una tenaz ociosidad podrá dejar de ejecutarlo.

El abono por medio de las quemas sólo puede tener lugar en las nuevas roturaciones, pues que debiendo estar las tierras limpias de toda yerba no puede llegar el caso de la quema. Pero si algun mal labrador tuviese plagado su terreno de yerbas, cuando estén secas, pegará fuego para que mueran las semillas.

Como los cosecheros filipinos acostumbran desacertada y perjudicialmente, como ya dije, 
á sembrar maiz despues del segundo corte del tabaco, luego que lo recolectan, dejan con el mayor descuido y abandono todas las cañas ó matas secas y sin cortarlas ni rozar siquiera meten el arado para la nueva sementera.-Tal práctica no merece disculpa alguna, pues representa ociosidad, abandono y la grande suciedad del labrador.

¿No han observado, despues de tantos años, que no sólo la caña del maiz sí que tambien en el mismo corazon del pabílo de la panocha se desarrollan, crecen y multiplican cierta. clase de gusanos articulados que roen, enferman y hasta matan las plantas? ¿No han notado aún cómo las atacan en la base del patron cuando son pequeñas y tiernas, esto es, entre dos tierras y royendo el tronco las enferman y matan? ¿No han visto lo mucho que atrae y produce de dichos gusanos la referida planta, los que se fijan en ella y despues hacen sus ovaciones en el mismo peciolo de las hojas? ¿No han saboreado alguna vez la sustancia dulce de dicho vejetal, por cuyas propiedades los referidos gusanos son tan aficionados á él, y en el que despues de vivir y ovar se conservan estos elementos perjudiciales para reproducirse en la siguiente sementera? Pues si todo esto es rerdad y muy á la vista, ¿cómo no segar y reunir en montones, des- 
pues de cojer el maiz y quemar dichas matas? Si no han querido observarlo ya saben de dónde procede parte de la grandísima suciedad de las tierras y el orígen de cierta clase de gusanos que plagan los tabacales, además de lo que, por instinto especial, son más afectos á la sustancia narcótica del tabaco.

El otro abono consiste en el que naturalmente producen las inundaciones de los rios y esteros en tiempo de grandes lluvias ó tempestades sobre las tierras bajas contíguas á los mismos, á las que se dá el nombre de veyas y valles. Este abono natural es de los mejores por las diferentes sustancias mineralógicas que arrastra la denudacion de las montañas; por el acarreo de restos rejetales, animales y fosiliferos, cuyos elementos combinados yacen sobre dichas vegas y valles despues que desaparecen las aguas del aluvion.

Estos abonos son de más ó ménos beneficio segun los elementos geológicos de las montañas de que proceden. En las islas Filipinas, cuya constitucion volcánica es evidente, los abonos que proceden del aluvion benefician mucho las tierras, pues los estratos sedimentarios que de más ó ménos espesor se forman sobre ellas, son de un carácter enteramente nutritivo para la vejetacion.

Resumiendo: buenos y repetidos barbechos 
para que se beneficie la tierra con los elementos atmosféricos y muera toda clase de yerbas: descanso á los terrenos en labor, más ó ménos prolongados, segun convenga: abonos con buenos estiércoles, tanto más fermentados y en abundancia mucho mejor: escardas, cavas y binas á tiempo, bien hechas: riegos, con oportunidad, álas tierras que lo tengan: roce, corte y quema de todas las matas del tabaco y maiz despues de la recoleccion; y si en el terreno se hubiese sembrado arroz, despues de cogido, quema al rastrojo; y si de añil ó caña dulce, fuego tambien.

Estos son los abonos más generales para el buen cultivo de las plantas, y que solamente. un mal labrador deja de dar á sus tierras; no creyendo ocioso decir á los filipinos el fácil modo de hacerse de buenos estiércoles para abonarlas.

En un rincon del solar de la casa se vá echando toda la basura y la limpieza de debajo de la misma y del batalán, formando monton, en el que se revuelve la de lic cuadra, la del mismo solar y hojas secas de árboles, toda clase de desperdicios vejetules y animales, la ceniza del calán, la basura de la calle junto al cerco, las conchas de mariscos, restos de cal, paja del arroz y cáscara del mismo, lodo de los baches repodridos y toda clase de des- 
perdicios susceptibles de podrirse y fermentar, arrojando siempre sobre el monton las aguas súcias, de jabon y orines, procurando, en lo posible, que los cerdos y las gallinas no lo deshagan con la trompa y las patas.

Cuando haya buena cantidad, se recorta con la azada para que se revuelvan bien todas las materias y sustancias, volviende á amontonarlo mejor que antes para que se repudran y combinen, en cuyo estado se dẹa preparado ya para llevarlo í la tierra que se va á beneficiar, valiendose para conducirlo al campo de las carromatas y enterrándolo lo más pronto para que el aire y el sol no le roben las propiedades de nutricion para las plantas que se quiere beneficiar á mano, ó abonar la tierra antes de la sementera que se va á hacer. 


\title{
SECCION SEGUNDA.
}

\author{
DEL CULTITO DEL TABACO.
}

\section{CAPITULO PRIMERO.}

DEL CLIMA I TIERRAS ÚTILES PARA TABACALES.

Si la influencia atmosférica ejerce tan poderosa accion sobre todo loviviente, la temperatura del Archipiélago filipino es sin duda alguna la más ventajosa quizá de todos los trópicos para la vejetacion. Tierras sedimentarias de origen volcánico, grandes lluvias y abun. dantes rocios, aluviones fértiles sobre las riberas de los rios y una temperatura á catorce grados por téruino medio, hacen que los tabacos de Filipinas, entendidamente cultivados y beneficiados, puedan competir con los mejo- 
res de Cuba y sobrepujar tambien en bondad, dimensiones y calidad.

En apoyo de esta opinion, resultado de mis observaciones prácticas en la primera coleccion de aquellas islas que á mi cargo estuvo, la confesion esplícita de los mismos cosecheros cubancs lo prueba. Dice uno de los más ilustrados y expertos, "que el Archipiélago filipino es un privilegiado clima para el cultivo del tabaco, en donde con una buena direccion en los trabajos de cultura, beneticiacion y elaboracion, no dudamos que seria en muy pocos años digno émulo del cubano. Los terrenos de Filipinas son generalmente buenos para dicho cultivo y algunos de ellos excelentes: para probar esta asercion basta examinar los productos: añádese, que en nada ayuda alli el hombre á la naturaleza y se comprenderí todo el partido que puede sacarse de una planta que, en el estado actual, es decir, medio silvestre, es ya una de las buenas que se presentan en los mercados.)

$\mathrm{Y}$ si esto dicen los mismos celosos émulos del tabaco filipino, ¡qué no podría yo añadir como resultado de mi constante observacion y estudios prácticos sobre aquél privilegiado país! ¿Qué no dirian aquellos si vieran el atrasadísimo cultivo $\mathrm{y}$ beneficio que en aquellas ieraces islas se le dá! 
No admitiendo duda alguna las buenas condiciones del clima y terrenos de aquel Archipiélago para el buen cultivo del tabaco, me ocuparé primero de las tierras mús útiles y á propósito para ello.

Es una verdad reconocida por la ciencia y la experiencia, que las tierras sedimentarias que se forman por la denudacion de las rocas volcánicas constituyen un terreno fértil, y que la sílice, la alúmina, la potasa, el hierro y la hornablenda, además de otras sustancias de que se forman dichos sedimentos, se encuentran allí generalmente en las proporcioaes convenientes para favorecer la más robusta vejetacion.

Tambien es una verdad evidente, que la constitucion geológica del Archipiélago filipino es de carácter volcánico, como lo atestigua. la figura conóidea de sus montañas, los cráteres apagados y en ignicion y, en suma, sus valles $\mathrm{y}$ vegas procedentes del arrastre $\mathrm{y}$ acarreo de las denudaciones y aluvion, en cuya variada si bien idéntica estratificacion se nota su incuestionable origen y condiciones quimicas para la más fértil vejetacion. Por consecuencia, cuasi todos los terrenos de Filipinas son buenos para el cultivo del tabaco, especialmente los bajos y llanuras que sitúan en los valles y riberas de los rios. Estas, pro- 
piamente llamadas vegas, son las tierras mejores por que se conservan más frescas $\mathrm{y}$ disfrutan del beneficio de las inundaciones y rocíos. Esta verdad es manifiesta en la extensi cuenca del coloso rio Cagayán, zona experimentada en donde se cosecha el mejor tabaco de aquellas islas; si de lamentar, que por falta de poblacion, se encuentren dilatadas extensiones de terreno inculto á uno y otro lado de los bosques que forman sus feraces orillas.

Lats colinas bajas y terrenos poco inclinados junto á los rios y grandes esteros de aguas corrientes son tambien, en segundo lugar, muy á propósito para el cultivo del tabaco, porque conservan más la frescura y son mayores los rocíos que en las tierras altas, que las trabaja el viento y las reseca mucho el sol.

Los terrenos altos, si bien se cria en ellos el tabaco, nunca son tan buenos como los bajos. porque la denudacion de la corteza terrestre y derretimiento de la superficie con las lluvias y tempestades frecuentes vá quedando la tierra sin elementos de nutricion para las plantas, los fuertes vientos la resecan y la accion viva del sol acaba de robar los jugos y humedad tan necesaria para la vida de ios vejetales: resultando, que el tabaco que en dichos terrenos se produce es mucho más corto en las hojas $\mathrm{y}$ de inferior calidad, si suave al fumarlo. 
Las nuevas roturaciones de bosques producen en el primero y segundo año mucho $\mathrm{y}$ buen tabaco, conservando sus buenas ó malas condiciones si el desmonte es en tierras bajas ó altas, y segun el mayor ó menor trabajo que en ellas dá el cosechero cultirando las plantas. El tabaco, pues, se cria bien en Filipinas en la mayor parte de sus terrenos conocidos y, ciertamente muy bien en los inmensos desconocidos. La prueba es, el buen tabaco que suelen presentar al aforo las tríbus salvajes más en contacto con los pueblos cosecheros, superior á veces en dimensiones y calidad al que se cultiva en estos.

Los terrenos pantanosos ni con encharques de aguas detenidas no son buenos para el cultivo del tabaco por sus condiciones desagradables luego para el consumo, pues si suelen dar. se hojas de buen tamaño en ellos, resulta horro ó que arde mal.

Son tambien malos terrenos para el cultivo los muy gredosos ó en los que se abren grandes y hondas grietas en los tiempos de sequía, p'ues el que producen es de malas condiciones, excesivamente fuerte, muy poca flexibilidad para la elaboracion, arde con desigualdad y la ceniza de mal color.

Las tierras ligeras ó de tercera clase producen regular tabaco para tripa, pero de poca 
consistencia y duracion, pues se pica ó apolilla con facilidad. Su mérito consiste en la suavidad al fumarlo, si con poco aroma, buen arder y color: pero hay que elaborarlo y vender pronto.

La cohiva ó tabaco, es un vejetal tan agradecido que si el labrador le prodiga oportunamente sus cuidados se afana, digámoslo asi, por crecer vigoroso y desarrollarse cuanto puede para recompensar con usura al que tantas veces lo acarició con sus manos y las de su familia: por el contrario, si le trata mal $y$ con desden el cosechero, no espere al tiempo de la recoleccion si no el triste desengaño que merece su descuido.

Respecto á las nuevas siembras que se hacen en la roturacion de bosques vírgenes, consiguiente es, como tengo dicho, que en el primero y segundo año se produzcan buenas cosechas, participando el tabaco de las buenas ó malas condiciones geológicas del terreno en que se cria, cuya bondad aumenta ó disminuye el clima, la clase de cultivo y la exposicion.

La mejor exposicion de los terrenos para el cultivo del tabaco es la de sol saliente, pues disfrutan lasplantas más tiempo de él que al Poniente y Norte: despues la del Mediodia es preferible; y en último caso, la del Norte. La del Poniente no es buena. 
En Filipinas hay que tener tambien muy en cuenta los monzones del Sud y del Norte, únicos vientos dominantes que fijan de por mitad la temperatura del año, además de las accidentales variaciones de localidad. Estos accidentes, más ó ménos sensibles, los produce naturalmente la situacion topográfica y la configuracior y altura de las montañas, cuyos vientos más reinantes ó perjudiciales en cada localidad saben bien los labradores y tendrán presente para las siembras y cultivo del tabaco, y para dar los riegos á la tierra que los tenga.

Tambien es importante que las tierras para tabacales no estén rodeadas enteramente de altos bosques; pues además de la falta de ventilacion tan necesaria para el robusto crecimiento de los vejetales, para el tabaco es perjudicial, por que sofocadas las plantas con el intenso calor se afogaran las hojas y cuaja mal la semilla; por que no reciben ni expelen bien el oxígeno y el hidrógeno atmosférico; por que adquieren mucha linfa, tan nociva al buen color, sabor y duracion del tabaco; por que asombradas las plantas, si bien crecen más, adquieren un carácter hidrópico que produce luego un insufrible amargor; por que despues se atiola más pronto en los almacenes; por que contiene ménos goma para su mayor duracion y buen elaborado y, por que, su color 
despues, por la falta de luz y desol en el talacal, no es limpio y de mal carácter.

La mejor exposicion y terrenos para el cultivo del tabaco son los que, por su órden, queclan explicados.

Resumiendo diré, que el tabaco se produce bien en toda clase de terrenos, excepto en los salinos, muy calcáreos, excesivamente arcillosos, con mucha greda y sin bastante fondo ó subsuelo. Que es una planta poco delicada para criarse y se acomoda á vivir en cualquiera temperatura y clima, salvo en los muy frios; que vive mejor y se desarrolla más en los cálidos y tropicales: que sus buenas ó malas condiciones pender muchas veces de la clase inadecuada del terreno en que se cria, de ía oscasez de abonos, mezcla de semilla, falta de ventilacion natural y mal cultivo: por lo que son preferibles para él las vegas, orilla de los rios y valles con frescura ó riegos, y las de aquellas regiones húmedas por grandes rocíos, espesas nieblas ó reiteradas lluvias. En segundo lugar las tierras más altas poco desniveladas y en iguales condiciones climatológicas. En tercer lugar cnalquiera otro terreno, aunque alto, con fondo labrable para el cultivo. Los de roturaciones de tierras vírgenes son los mejores, con la exposicion á sol saliente. 


\section{CAPITULO II.}

DE LA SEMILLA Y SEMILLEROS.

De todas las operaciones de la agricultura, en ninguna debe ponerse más esmero y proligidad que en la de escoger y conservar las semillas. El labrador que no lo hace el castigo se impone á sí mismo. ¿̨Puede nadie compren. der que de padres enanos, flacos $\mathrm{y}$ enfermos resulten hijos de gran corpulencia, robustos y sanos? Pues lo mismo sucede con toda clase de vejetales. Por consecuencia, todo esmero y proligidad es poca para escoger y conservar las semillas. $Y$ si tanto cuidado se necesita poner aún respecto de las más voluminosas, cuya perfeccion ó desperfectos está á la vista, ¿cuánto nó para con la del tabaco que es la más fina y menuda de cuantas el hombre cultiva?

Podrá tolerarse, por una vez tan solo, al labrador que en su campoó tierras resulten frutos mezclados aunque de fácil apartado sean al recolectarse; empero ninguna disculpa ni 
tolerancia en la segunda cosecha ó sembradura, por que tuvo tiempo más que sobrado para escoger buenas semillas de una sola clase con la separacion debida.

Nada más funesto para el labrador, repito, que la mezcla de semillas diferentes, por que unas plantas se adelantan más que otras en nacer, criarse y producir fruto; por que, segun la experiencia, cada cual necesita un distinto cultivo; por que cada una tiene su organismo diferente, aunque asimilado sea en su clase; porque mezclada degeneran los vejetales; por que las estaciones y tiempo convenientes para unos no lo es bueno para otras; y por que mezclados los frutos pierden en su valor $\mathrm{y}$ venta en los mercados.

Pero es tal el descuido en Filipinas para el buen cultivo del tabaco, que al señalar las plantas para semilla dejan indistintamente en la sementera cualesquiera matas sin elegir las más robustas y de una misma clase; la cogen despues sin hacer ninguna separacion, la solean y guardan sin ningun esmero dejándola llena de suciedad, de tierra, de polvo, de palillos y partículas delas gárgolas ó celdillas en que se contiene y así la dejan hasta la cosecha siguiente. Con bastante más cuidado la he visto conservar a los indios salvajes que siembran tabaco en los bosques, y observado 
que los frutos que crian son mejores en calidad, tamaño y bondad, no pocas veces.

Diré ahora el modo racional y útil de coger buena semilla y la manera de conservarla en buen estado de una para otra sementera.

Varias son las clases de tabaco que se cultivan en el Archipiélago filipino bajo diferentes nombres, segun el dialecto de localidad, y las que para más sencilla inteligencia pueden reducirse á cuatro: Cagayán, Igorrote, Gapán, y Visayo, bajo cuyas denominaciones lo conoce el comercio y paga el Estado. Nada importa, pues, la indígena nomenclatura de Pámpano, Minustasa, Isinay, y de Corazon. A las cuatro primeras clases hay que añadir el Habano, cuya semilla se importó últimamente de la isla de Cuba, y es muy conveniente al labrador para el sistema actual de aforo por pulgadas y lineas en la longitud de las hojas.

Cuando el tabacal se encuentra ya en estado de despunte ó como llaman los vegueros cubanos desbotonar, y antes de comenzar á él, se procede á la designacion de una sola clase de tabaco y señalamiento de las matas que se destinan para semilla, quitándolas las hojas de arriba con la podadera, á fin de no causar heridas en el tallo principal, como resultan haciéndolo al desgaje con la mano, y por las que se ventéa el patron de la mata y dests- 
tancia con la pérdida de sávia tan necesaria para la vida y robustez de aquella. Estas no son minuciosidades si no para los imperitos y malos labradores.

Dicha operacion trae ventajas, pues haciéndolá tiempo, como llevo dicho, puede aumentarse cuanto se quiera el número para semilla segun la discreta prevision del cosechero, quien debe precaverse mucho para las contingencias futuras. Estas, pueden ocurrir por sequía, muchas lluvias, malos vientos, enfermedades, gusano, y tempestades, para cuyas eventualidades debe ser muy precavido dejando bastantes plantas señaladas, por si se le inutiliza parte de la semilla ó quiere luego sembrar más tierra al tiempo de hacer los semilleros, y con el fin tambien de formar varios, unos más tempranos y otros tardíos.

Al labrador descuidado que por imprevision ó abandono le faltase semilla al tiempo oportuno, no solo no le daría ro un grano ni una mata siquiera de mis semilleros, sí que me seria indiferente su hambre y su miseria despues. Ni áun caridad merece el ocioso, el holgazan y mal labrador.

Despues de señaladas las matas para semilla se procede al despunte de todas las demás; y cuando las hojas del tabaco se encuentran ya en buena sazon ó maduro, como dicen los co- 
secheros, se procede al corte de aquella, cuyo estado de madurez se conoce por el color algo oscuro que toman las hojas y las gárgolas que contienen la semilla. Entonces, ya sea antes $\delta$ despues del corte general de la hoja, v en una mañana clara con sol, se cortan con la podadera las puntas de semilla á dos palmos de largo por bajo de las últimas gairgolas, sin sacudirlas; y formando manojos se cuelgan al aire bajo techado y resguardados del viento fuerte por espacio de un mes, para que se acabe de secar.

Curada ya la semilla, en un dia claro y sin viento fuerte, sobre una sábana tendida en el. suelo se sacuden los manojos y deshacen las gárgolas con las palmas de las manos, y no con golpes, pues se lastiman muchos granos. Acto seguido se aventa sobre la misma sábana, procurando quede muy bien limpia la semilla, sin tierra, polvo, cáscaras, palillos ni otra suciedad. Despues se deja extendida al sol removiéndola de vez en cuando, y se echa en una tinaja nueva, $\delta$ que no haya servido en otros usos domésticos, despues de soleada, para quitar toda humedad y mal olor. A seguida se tapa con un pedazo de tabla redondo que ajuste bien con la boca de la tinaja, y con resina ó pez derretida al fuego se cubren muy bien las juntas de la tapadera, 
sin dejar claro alguno por donde entre aire, luz ni hormigas, y se guarda en sitio seco ó sin humedad hasta el tiempo oportuno de los semilleros.

De este modo sufre ménos la influencia atmosférica, no se descompone ni altera, no la atacan los insectos ni destruyen las ratas. Este fué el método que mandé observar durante mi gobierno y administracion en la colectora provincia de Cagayán.

A falta de tinajas puede guardarse en grandes bombones ó canutos de caña Cauayan-boo, tapados por la boca en los mismos términos que he dicho para las tinajas, los que se cuelgan de las maderas del techo ó quízame en las habitaciones de dormir.

La semilla debe sacarse nueva todos los años y no guardar la vieja, procurando renovarla cada tres para que no degenere.

\section{SEMILLEROS.}

Los semilleros se forman y siembran de la manera siguiente. En un sitio lo más próximo á la habitacion del cosechero ó de su morada en los tabacales, que no sitúe tan bajo 6 expuesto á la inundacion de aluviones de terre- 
nos más altos y á sol saliente, en paraje despejado de bosques, cercas, tapias ni edificio, se traza la extension del semillero y cava bien con el azadon un par de veces la tierra con intermedio de dos ó tres dias, si está muy húmeda, revolviendo en la segunda cava proporcionada cantidad de buen estiércol repodrido y menudo. Despues, cuando ya se vá á formar el colchon del semillero, se dá una tercera cava para recortar bien la tierra, revolver más el estiércol y mullir aquella.

Hecho esto, cuando tenga buena sazon la tierra y antes que pierda el jugo, se divide el colchon por medio de zanjas á lo largo, y con la misma mullida tierra estercolada se forma á uno y otro lado dos semilleros, separados como á una vara, y quedando más elevados que 10 restante del terreno. Por medio de dichas zanjas con desagüe, se evita la inundacion de las lluvias y facilita el paso para cuidar de ellos, sembrar, entresacar, regar, matar el gusano y arrancar la planta para los trasplantes en las tierras preparadas.-La direccion de las zanjas debe darse de Norte á sud para que los semilleros reciban más por igual el sol primero de la mañana, que es el inejor.

Acto seguido se allanan dichos colchones ó eras todo lo mejor posible, quitando los ter- 
rones y piedras que haya, dejando la tierra perfectamente menuda y suelta. Despues se barre con una escoba de rama de las que en el país se usan para la limpieza de las casas y acaben de salir todas las piedrecillas y terrones que haya en la superficie del colchon, procurando dejarla bien llana y sin hoyos.

Inútil es advertir, que debe hacer el cosechero más de un semillero para que no le falte planta y precaverse de lo que pueda ocurrir por gusanos, enfermedad, tormentas, vaguios, ú otros accidentes. Más vale que sobre planta que luego falte una sola mata en el trasplante, para lo que hará dos tandas: unos más tempranos y otros más tardíos en las menguantes de las lunas de Agosto y Setiembre.

Preparados así los colchones ó eras y con la suficiente humedad para que la semilla germine, rompa y nazca, si el tiempo está sereno y no amenazan lluvias, se procede acto seguido á echar la semilla de la manera siguiente.

Primero, se revuelve con arena fina que esté seca ó con ceniza menuda en la proporcion de mitad y mitad: esto es, un puñado de semilla y otro de arena ó ceniza, revolviéndolo muy bien. El objeto de poderse mezclar tambien con ceniza es, para que adherida á los granos les sirva de beneficio para el más pronto des- 
envolvimiento, no la roben las hormigas ni ataquen otros insectos. Acto contínuo se hacen con el dedo ó con un palito rayas ó señales de trecho en trecho al través del colchon yá distancias iguales que sirvan de guia al sembrador; el que cogiendo medio puñado de la semilla preparada y con la vista fija sobre la tierra, la empezará á tirar ó esparcir á vuelo con suavidad, prontitud é igualdad, llevando la mano baja para que aquella no se la lleve el viento, cuya operacion se verificará en un dia que no lo haga fuerte. Despues se pasa por encima la escoba de rama con suavidad, ligereza é igualdad, primero hácia un lado y despues hácia el otro, con el fin de que se reparta bien la semilla, no quede aglomerada y entierre: y seria muy conveniente cerner con un harnero ó biláo, mantillo de estiércol muy menudo ó pulverizado sobre todo el colchon una ligera capa de aquél y se riega despues con mucha igualdad todo el semillero.

Sembrado y regado el semillero se clavan por ambos lados del colchon estacas de trecho en trecho, á iguales distancias, que sobresalgan como tres palmos de aquél, y de una á otra se atraviesan y atan unas caũas largas ó palos delgados formando como un emparrado, con el fin de poner encima algunos tapancos ó sombrajo de quita y pon, hechos de cógon ó 
de estera de palma, para resguardar el semillero en las horas de sol fuerte $\delta$ cuando sobrevengan aguaceros grandes. Esta precaucion es muy importante.

La operacion de echar ó esparcir la semilla es delicada y requiere bastante experiencia ó práctica en el sembrador, pues si no la reparte con igualdad, resulta luego el semillero en un lado muy espesas las plantas y en otros muy claras ó ningunas. Excuso advertir, que no se ponen los piés sobre el colchon cuando se está sembrando, ni las manos tampoco despues, y que todas las operaciones se ejecutan por uno y otro lado andando por las zanjas.

Como sea en la práctica una mentira cuasi en Filipinas la utilísima institucion de «Jueces de sementeras, de policía, y de ganados" en cada pueblo, es una necesaria precaucion que el labrador cerque bien sus semilleros con un vallado de estacas largas ó con cañas bojas para guarecerlo de los animales: cosa fácil y sin costo en aquél país en que tan á la mano se tiene cuanto quiere para ello, sin más que coger el bolo y empezar á cortar lo que se necesita.

Si el estado higrométrico de la tierra es bueno y el calor no excesivo, nace el tabaco á los seis ú ocho dias, cuyo nacimiento se adelanta ó retrasa segun el estado de la at- 
mósfera y la mejor ó peor preparacion del semillero. Si sobreviene sequía y no nace pronto el tabaco, ó se nota sentimiento en las plantas por falta de humedad, entonces con una regadera de lluvia fina se riega despacio y con mucha igualdad el semillero antes de ponerse el sol ó por la mañana al romper el dia.

A falta de regadera, que á ningun cosechero de Filipinas le es fácil adquirir, se darán los riegos á mano echando agua dentro de un biláo grande puesto sobre el semillero, y con él se vá repartiendo el agua con igualdad, . teniendo cuidado de no encharcarlo, por que la excesiva humedad pudre las muy finas $\mathrm{y}$ tiernas raicitas de las plantas. Los riegos, pues, deben ser proporcionados, iguales y sólo cuando el semillero lo necesite, y nunca con aguas salobres ni corrompidas: jamás con orines, como en una ocasion ví á un estúpido é ignorante labrador.

Cuando el viento arrecia por un lado, por el mismo se ponen de canto los tapancos para guarecer el semillero y evitar los perjuicios que en el mismo hace aquél resecando la tierra, revolcando las matas y tronchando las más tiernas.

Luego que las posturas son algo crecidas, se procede á aclararlas en aquellos sitios que nacieron más espesas, cuya operacion se hace 
despues de una lluvia ó riego á mano la tarde anterior al ponerse el sol, entresacando con toda proligidad y cuidado aquellas más delgadas y endebles, dejando claras las sanas y robustas. Dicha operacion se hará despacio y sólo con los dedos sin meter palo, caña ni otra herramienta alguna.

Despues de nacidas las plantas registrará diariamente el cosechero sus semilleros para ver si hay gusanos, los que matará al instante y sin parar hasta que no quede uno. Por esta

- razon dije antes que los semilleros debe formarlos el labrador lo más cerca posible de su habitacion. ¿Qué sucede á aquellos que los hacen á gran distancia de su morada? Que cuando van á visitarlos se los encuentran á veces lestruidos yá enteramente, cuyo perjuicio es irreparable.

Al cuidado anterior debe añadirse el de las escardas á mano para tener bien limpio el semillero de toda clase de yerbas; 10 que se ejecutará despues de un riego ó lluvia y en los mismos términos explicados yá para aclarar las matas del tabaco: esto es, con los dedos y sin meter palo, caña ni otra cosa.

En Filipinas se acostumbra hacer dos siembras de tabaco; una más temprana en tierras altas y otra más tardía en las bajas y vegas contiguas á los esteros y rios. No es mal mé- 
todo, si en la ejecucion se supiera allí más de agricultura.

Como en aquél país llueve tanto y sobrevienen inesperadamente grandes cataclismos atmosféricos, se precaven algo los cosecheros con las siembras tempranas en los terrenos altos por lo general, cuyo fruto suele ser de inferior calidad y miga. No obstante, se coge en algunas tierras altas escelente tabaco, que prueba la bondad del clima para su cultivo. Tambien se hacen trasplantes tempranos en las bajas para que toda la cosecha no se venga á la vez y el corte sea luego progresivamente continuado.

El arranque de las plantas ó posturas para la siembra de los tabacales debe hacerse despacio y con mucho cuidado, cogiendo aquellas con la punta de los dedos de la mano derecha bien pegados á la tierra, con el fin de coger la planta por el nacimiento del tallo junto á la raiz, y se tira con suavidad hácia arriba procurando salga íntegro el tronco con todas sus raicitas. En esta operacion debe ponerse mucho cuidado para no inutilizar planta.

Conforme se vá arrancando, se hace manojos que se atan en el acto con cualquiera filamento y se ponen á la sombra con las raices para abajo en un sitio fresco que se riega al intento préviamente, y desde el que se llera cubierta 
con hojas verdes de plátano ú otras yerbas frescas á la tierra preparada para tabacal y se comienza á sembrar lo más pronto posible.

Si el terreno preparado para la siembra estuviese lejos del semillero, el arranque debe hacerse la tarde anterior, $\delta$ al rayar el dia, segun la distancia. Si está cerca, conforme se vá arrancando la lleva un muchacho ó mujer y las demás no paran el trasplante.-Es muy bueno, si hay agua á la mano, lavar las raices de la planta para que no lleven tierra, lo que fácilmente se ejecuta cogiendo los manojos uno á uno por las hojas y metidas las raices en el agua se sacuden.

Resumiendo: debe ponerse todo cuidado y esmero en la eleccion, separacion por clases y conservacion de la semilla, cogiendo y guardando doble cantidad de la que se piensa sembrar en la siguiente cosecha: sacar de ella anualmente semilla nueva, renovándola cada tres años y no sembrar de la vieja: preparar bien con varias y buenas cavas la tierra para los semilleros, abonándola con buen estiércol, echarlos con anticipacion oportuna, suficiente humedad, buen tiempo, y en las menguantes de Iuna; guarecerlos del sol fuerte, vientos duros y tempestades con buenos tapancos ó sombrajos: regar á tiempo y con discrecion en los de sequía y vientos fijos: entresacarlos con 
oportunidad y cuidado: tenerlos limpios de yerba; cercarlos con buenos vallados; visitarlos diariamente; matar sin tregua los insectos y gusanos; ejecutar el arranque con la fresca, con mucho cuidado y la tierra húmeda; lavar las raices de la planta antes de la siembra; y no prestar, en fin, á nadie absolutamente, $n \mathrm{i}$ una sola mala ó postura, si no hasta despues de haber concluido de sembrar y reponer todas las tierras preparadas para tabacales.

\section{CAPITULO III.}

DEL TRASPLANTE Y RIEGOS.

Preparadas las tierras para sembrar en los términos explicados en el capítulo quinto de la seccion primera con dos barbechos y bien estercoladas, en proporcion al estado y condiciones del terreno, cuando se vé que las plantas del semillero se encuentran ya en disposicion para el trasplante y aquellos con la humedad necesaria, antes que se pase ésta, inmediatamente se mete el arado y se dá una buena reja ó labor bien yuntos los surcos. Acto segui- 
do se tablea y desterrona con un mazo de madera como de unas seis ú ocho libras de peso, en el que por un agujero se mete un mango largo y delgado como de siete palmos.

Así ya la tierra, se procede á señalar los liños en que se han de sembrar las matas, cuya operacion se ejecuta liaciendo antes con el arado y á iguales distancias, surcos hondos, anchos y muy derechos de Saliente á Poniente, procurando que resulten lo más exactas posible las distancias de uno á otro. Despues se cruzan de Norte á Sud exactamente á la misma distancia que los primeros, con el fin de que resulten cuadros iguales, en cuyos ángulos se siembran las plantas. Dicha operacion se hará en el mismo acto de ejecutar el trasplante, teniendo ya dispuesta la gente que ha de verificar la siembra: pues si los liños se abren y deja pasar tiempo, el sol y el aire secan la tierra. Por lo que y con el fin de que las caras interiores del surco conserven la humedad y frescura, en tanto que se implantan las matitas ó posturas de tabaco, el hombre que los abre vá despacio y poco á poco delante ejecutándolo segun adelantan las sembradoras.

Al hacer los liños se debe tener presente la clase de terreno y la del tabaco. Si son tierras bajas ó vegas de buena calidad, con riego y bien estercoladas, la distancia de surco á surco 
será de cinco palmos si el tabaco es de los que por su naturaleza producen hojas largas y anchas: si es del que las dá más cortas, la distancia de dos tercias á una vara; y en el caso de estar la tierra cansada yá, sin estiércol y enteramente esquilmada, la distancia será prudencial, y lo mejor no sembrarla sin dar antes el beneficio correspondiente. Cuando las tierras son altas, la distancia será mayor, teniendo en cuenta el clima, la estacion, los abonos y carácter del terreno, cuyas circuns. tancias sólo puede apreciar bien la experiencia y observacion del labrador.

No obstante lo dicho, aconsejo lo que yo haria siendo cosechero: de hacer las siembras del tabaco bien claras, pues cuanto más ventiladas tanto mejor para el desarrollo de las hojas, mayor calidad y peso, ménos expuestas ¿ afogararse, facilidad para la limpia del gusano, labor de las matas, despunte y corte del tabaco sin estropear, romper ni mutilar las hojas. Esto es más aplicable en Filipinas con el actual sistema de aforo.

Reunidos ya en la misma tierra preparada los sembradores y hechos los liños cruzados, sin perder tiempo se reparte la planta, dejando en cada uno de los ángulos una mata y á seguida, puestos aquellos en ala, coge cada cual dos liños de frente y todos á la vez continúan 
haciendo el trasplante ó siembra de la manera siguiente.

Con el almocafre en la mano derecha se dá un golpe ó clava en la tierra; y al tiempo de sacarlo, en el pequeño hoyo $\delta$ abertura, teniendo en la izquierda la plantita de tabaco, se coloca dentro con las hojas hácia arriba procurando no poner las raices sobre piedra, canto ó terron duro que haya; y apretando la tierra con la misma herramienta junto al tronce, ó con los cuatro dedos primeros de ambas manos, se deja derecha con las hojitas limpias y sueltas, quitando las piedras ú otros embarazos inmediatos á ella.-No se debe apretar tanto la tierra que lastime el tierno tallo de la postura, ni quede aprisionado para crecer; ni dejarse tan floja ú holgada que penetre el aire y rayos del sol, cosa muy perjudicial tambien.

Al sembrar la postura ó matita se tiene sumo cuidado para no enterrar el nacimiento de las hojas ó sea el cogollo de la planta, ni que dentro ó sobre él quede piedra, terron ni otro obstáculo alguno, ni quede tampoco ninguna de sus hojas bajo de tierra: cosa bien sencilla de hacer, dejando limpia la superficie que circunvala el tronco y á la vez se forma una pocita que reciba $\mathrm{y}$ contenga el riego que á mano se dé alrededor del tallo de la mata, si á la tierra falta humedad. 
Despues, pero todo en el mismo acto, se cogen dos terrones de los más grandes que haya próximos y se colocan de punta ó canto hácia sol saliente uno y el otro al Sud ó Mediodia juntos y formando ángulo, para que con su sombra cubran algo la mata. A seguida y sin mover los piés, se ejecuta en el ángulo del otro liño al lado la misma operacion, y de frente en ala los sembradores continúan la siembra ó trasplante sin dejar falta alguna. El trasplante ó siembra debe ejecutarse desde antes de salir el sol hasta las nueve de la mañana: $\mathrm{y}$ desde las cuatro de la tarde hasta el oscurecer.

Si el tiempo se mantiene seco en los dias del trasplante, si la tierra no es de riego ó tiene poco jugo, segun se vá sembrando, otras personas riegan á mano todas las matas, derramando junto al tronco de cada una como cuartillo y medio de agua, cuya operacion se hace con igualdad por medio de una vasija ó tabo que contenga dicha cantidad. Este riego á mano se repite los dos ó tres dias primeros á la caida de la tarde, con el fin de que la planta se asegure en el nuevo terreno y empiece á echar raices. Al ejecutar dichos riegos no se echa el agua encima de los hojas ó cogollo de la matita, si no con la mano baja alrededor del tronco, para evitar que ninguna de las 
hojitas quede pegada á la tierra, pues indefectiblemente se secan y hasta matan el tallo principal.

Despues de sembrado un tabacal, al cuarto. dia y siguientes, se visita con mucho detenimiento para ver las matas que indican haber. muerto y reponer las faltas al instante, á cuya. operacion se llama resembrar, con el fin de que no queden claros ni faltas en los liños y que las reposturas crezcan á la vez con las otras matas. Si esta operacion no se hace ó retrasa, sucede que el labrador pierde las matas que dejó de reponer; ó las reposturas se quedan muy atrasadas y raquíticas, pues las primeras matas las sofocan con su mayor crecimiento.

Hecho el trasplante en los términos explicados, permanecen las matas de ocho á diez dias en un estado de paralizacion aparente, en tanto que empiezan á echar nuevas raices; desde cuyo momento se nota en el color y firmeza de las hojas estar ya asegurada la planta y creciendo con vida propia en el nuevo terreno, lo que se conoce bien á los veinte dias, ó poco ménos, por las nuevas hojas que aparecen. En tanto, no hay que alarmarse aunque permanezcan algo marchitas en lás horas de sol fuerte: diferenciándose mucho de las plantas muertas que, como llevo dicho y repetiré, deben reponerse sin perder tiempo. 
Cuando la estacion oportuna del trasplante avanza y las plantas del semillero no dan espera, por encontrarse ya muy crecidas y próximas á endurecerse, no se debe retrasar la siembra preparando la tierra con un riego, si lo tiene y carece del jugo necesario: ó se ejecuta con riegos á mano para no comprometer la cosecha si se pasa la estacion conveniente.

La mayor parte de las causas de muerte de las plantas pueden precaverse observando las reglas explicadas anteriormente: no así las atmosféricas, de tempestades, vaguios, ardientes soles, vientos sofocantes, y la plaga de insectos destructores. Por lo que al resembrar una planta muerta se observará si está roida, y entonces se remueve la tierra del hoyo y circunferencia, se busca al insecto ó gusano y matan cuantos haya.

Excusado parece repetir que se debe evitar la en trada de animales y personas extrañas en los tabacales nuevos, ni en los ya grandes, cuya vigilancia no debe olvidar el buen cosechero.

Resumiendo: las plantas de tabaco mueren por varias causas, ya porque el nuevo terreno es distinto en condiciones geológicas del en que se hizo el semillero, ya porque se lastimo ó mutiló sensiblemente la plantita ó postura al tiempo de arrancarla: ya porque en este es- 
tado estuvo más del conveniente: ya porque arrancada estuvo á la intemperie calorosa mucho tiempo y sus raices se ventearon: ya por intensa sequía y sofocantes vientos despues del trasplante: ya por continuadas lluvias que sobrevienen $\mathrm{y}$ encharcan las tierras: ya por falta de riegos á mano en los primeros dias del trasplante, si el calor es intenso: ya porque se hizo la plantacion con el fuerte sol de medio dia: ya porque al tiempo de la siembra se lastimaron las tiernas raices ó tallo de la plantita, ó quedó éste muy enterrado: ya porque se apretó mucho la tierra ó floja quedó al sembrarla: ya porque se pisó la mata ó cayó encima una piedra: ya porque los insectos y gusanos las roen por debajo ó encima de la tierra: $\mathrm{y}$ por otros accidentes en fin.

\section{CAPITULO IV.}

UEL CULTIVO Y ENFERMEDADES DE LAS PLANTAS.

Hecho el trasplante y resiembra de la manera explicada en el capítulo anterior, á los veinte dias ostenta ya el tabaco sus nuevas 
hojas con más ó ménos vigor, segun el estado y condiciones del terreno, la mayor ó menor humedad atmosférica y jugo de la tierra, cuyo buen estado 6 malas labores de la siembra se conoce en el color de las plantas, en su robustez y en su crecimiento. Si el calor es escesivo, los rocíos escasos y el jugo de la tierra poco, entonces tardan más en asegurarse con nuevas raices y crecer las hojas.

Cuando las plantas tienen la altura de un pié ya, si el tiempo es caloroso ó seco y el terreno de regadío, se dá uno ligero sin encharcar la tierra: pasados uno ó dos dias, y cuando está ya suelta ó no muy húmeda, se practica la primera escarda con herramienta, rompiendo la costra de la tierra, matando la yerba $\mathrm{y}$ aporcando ligeramente los troncos ó piés de las matas, sin que caiga dentro del cogollo piedra ni terron alguno, de manera que quede suelto el tallo principal y guarnecida la planta con la tierra suelta que se le arrima. Al remover la tierra de alrededor del tronco y sin lastimarlo, se observa si existen ovaciones de gusano. Este cuidado se ha de tener tambien despues al dar la cava y la bina con el mismo fin. In útil parece advertir, que tanto en la escarda como en las demás labores, se debe cuidar mucho de no estropear ni romper las hojas. 
La labor de escarda debe darse á las siembras desde muy temprano de la mañana hasta las diez de ella, y por la tarde desde las cuatro á puestas del sol, procurando quede tendida la yerba que se arranque para que muera, y mejor sacarla á las orillas del tabacal. Cuando el tiempo esté lluvioso ó muy húmeda la tierra no se dará labor alguna en ella, ni pisará, excepto en el caso de gusanos. Si el terreno no fuese de regadío $\mathrm{y}$ el tiempo continuase seco, entonces deben aprovecharse solamente las primeras horas de la mañana con el fin de que la tierra fresca y algo húmeda con el rocío de la noche anterior, refrigere $\mathrm{y}$ beneficie las tiernas matas. En medio del dia jamás se dará labor alguna.

Cuando las plantas han crecido y están á la altura de la rodilla, entonces se procede á la segunda é importante labor de cava, prévio un ligero riego si el tiempo estuviese seco y los rocíos escasos, cuya operacion se hace con la azada cortando y removiendo bien la tierra, con la que se irán aporcando las plantas, desterronando los que salgan y matando la yerba que expuesta quedará al sol.

La cava se hace de piés y en ala los cavadores, de dos en dos pasos de distancia de uno á otro, y á la vez y por igual llevarán la labor de frente, sin retrasarse ninguno, cortando y 
desmenuzando bien y por igual la tierra para que la de abajo salga al sol á beneficiarse con los elementos atmosféricos.

Entre la cava y primera escarda el buen labrador dará otra á mano, aprovechando alguna ligera lluvia ó grandes rocíos para arrancar la yerba antes que florezca y cuaje la semilla, cuya operacion se ejecuta con la mano derecha vuelta hácia abajo y el dedo pequeño hácia el cielo para coger bien la mata con los dos primeros dedos sobre la misma tierra, con el fin de asegurar bien la mata, muy á raiz del tronco, y se tira hácia arriba con firmeza y sin aflojar los dedos. Si así no se hace se descabezan las jerbas, quedando en la tierra el tronco y raices, las que á poco vuelven á retoñar y crecer con más vigor. Los tabacales deben estar siempre limpios de toda clase de yerbas.

A los quince ó veinte dias está ya el tabacal bien crecido y las hojas desarrolladas, en cuyo estado la siembra presenta un hermoso color verde, á que llaman los cubanos platear, ó que la plantacion platea. Con efecto, movidas las hojas por el viento resultan á la vista unos hermosos tornasoles que la luz produce en las películas del reverso de aquellas, ordinariamente de un verde más claro que en el anverso. Cuando la siembra ó plantacion se 
encuentra ya en este estado, se procede á desbotonar, como dicen los vegueros americanos, ó sea al despunte de las matas sin dar tiempo á que más crezcan ó empiecen á presentar las flores.

La operacion del despunte es una de las más delicadas, pues requiere el acierto de larga experiencia agrícola y de ello pende no pocas veces el mejor ó peor resultado de la cosecha. Por 10 que es una práctica nociva en Filipinas ejecutar dicha operacion por medio de muchachos y mujeres, sin otro cuidado que cortar solo cogollos á las matas.

El despunte se ejecutará de la manera siguiente: Lo primero es observar el vigor y desarrollo de la mata, á la que segun su estado, clase del tabaco y condiciones del terreno se la dejan, en los de buena calidad y regadío: catorce ó quince hojas, si la plantà es robusta, sana y crecida con exclusion de las dos inferiores que tocan á la tierra. Hecha la referida observacion, se coge el tallo principal de la mata con la mano izquierda, asegurándolo hácia abajo y con la derecha se descogolla ó despunta con la podadera por la última articulacion ó nacimiento de la hoja superior á la última de las que se dejan: despues se cortan las dos más bajas de la planta que están cerca de la tierra; y si á ella tocan tres, 
lo mismo, pues estas generalmente son inútiles, cuya sávia toman en menoscabo de las otras hojas buenas.

El objeto de asegurar con la mano izquierda hácia abajo el tallo principal de la mata es, para que al despuntar hácia arriba no se resientan las raices; cosa bien perjudicial para el crecimiento y vida de la planta.

En los terrenos de segunda clase, ó en los de primera que estén cansados ó con excaso abono, se dejan sólo de diez á doce: y en las tierras ligeras, ó á las plantas débiles, dos ó tres ménos en relacion á su estado de salud y potencia del terreno. Todo es relativo, cuyas apreciaciones solamente puede hacer la experimentada práctica. Razon por que dije no deber fiarse dicha operacion á personas no entendidas que, sin saber, pueden causar perjuicios irreparables.

En Filipinas, donde hoy se aprecia el tabaco por la longitud de las hojas, sin que su peso, miga, sabor ni aroma, ni demás condiciones que caracterizan al buen tabaco, suelan estimarse en el aforo, es tal la ignorancia de los cosecheros en algunas localidades que çreen, que cuantas más hojas dejen á una planta tendrán mejor cosecha. La contraria realidad no ha podido convencerles aún de su error.

Es una verdad sabida en todos los mercados, 
que el precio de la hoja para capas gruarda frecuentemente la proporcion de cuatro á cinco más que el valor de la destinada para tripa, como generalmente sucede con el tabaco cubano que se cosecha en la Vuelta de abajo, va se venda al peso, por manojos ó fardos. La razon es, por que la hoja corta ó mutilada sólo sirve para tripa y ésta abunda siempre; en tanto que para la de capas se necesitan hojas sanas y de buen tamaño que son las ménos ó más escasas. Por consecuencia, más valen ocho hojas buenas, grandes $y$ útiles para capa, que diez $y$ seis cortas para tripa.

Pasados diez ó doce dias despues del despunte se dará con la azada una ligera labor á la tierra, á cuya útil operacion se llama binar y á la cava ésta bina: utilísima labor, repito, para las plantas y tanto, que á los dos ó tres dias se nota el mejor color de ellas á cuya siembra se le dará el último riego de pié, si lo tiene, y se procede despues, pasados unos dias, á quitar todos los mamones é hijos que tengan. A esta operacion llaman los americanos deshijar. Su ejecucion es bien sencilla, si bien debe hacerse con esmero para no resentir el peciolo de las hojas ni causar á estas menoscabo alguno: para lo que, no se tira ni desgajan los tallos, si no que se cortan con la podadera ó con las uñas dela mano, pues son bastante tiernos entonces. 
Estos tallos salen y crecen en el nacimiento del peciolo de cada hoja, los que deben cortarse todos á raiz, igualmente que los mamones ó hijos que salen cerca de tierra en el tronco de la mata. Estos y aquellos deben quitarse á las plantas en todo tiempo que aparezcan desde que se hace el trasplante, procurando, repito, no desgajar para que no se resientan y más cuando e mpiezan á presentar el melazo, á que llaman los filipinos goma. Regla general: ninguna mata de tabaco debe tener más que un solo pié, sin otros tallos, hijos ni mamones.

Que los terrenos de regadío producen cosechas más seguras y abundantes es verdad; pero tambien que el tabaco cogido en ellos no es de tan buenas condiciones como el que se cria solamente con los grandes rocíos y $11 u-$ via: por lo que deben economizarse los riegos de pié $y$ solo darlos en grandes sequías para humedecer la tierra antes de la escarda, cava, y bina. El riego escesivo ó las muchas lluvias hacen que resulten luego las hojas de mal color, á que llaman los vegueros tabaco pajizo. Por el contrario, cuando escasean las lluvias y rocíos, resultan ásperas, quebradizas y con una fortaleza desagradable.

Resta ocuparse ahora de la operacion más entretenida, más molesta, más penosa y urgente 
de todas las en que el labrador se ocupa para cosechar tabaco: esta es la de matar los gusanos. Tan importante es al cultivador ó veguero el guardar sus plantaciones de los insectos que las devoran instantáneamente, que el más pequeño descuido en vigilar la siembra basta para que momentáneamente quede destruida. Extraño parecerá que haya insectos aficionados á alimentarse con preferencia del amargo, ácre y narcótico jugo ó sávia del tabaco; sin embargo, es una realidad fatal para el labrador dedicado á su cultivo.

Tambien parecerá increible la prontitud con que dichos insectos destruyen una plantacion: basta una noche para ello, pues de dia no comen tanto ó roen ménos. De manera que, ocurre con frecuencia visitarse hoy una siembra sin aparecer síntomas ostensibles de la existencia de ellos, y al siguiente dia verse yá los estragos causados. Por tanto, el buen cosechero no debe descuidarse en visitar diariamente sus plantaciones para precaver los efectos terribles é irreparables del gusano.

No hay época fija en su aparicion, pues á veces se presentan cuando las matas apenas se acaban de trasplantar: en el mismo semillero aparecen y los destruyen en un momento. Por ello, repito, que todo cuidado es poco para evitar sus funestas consecuencias que, de 
ordinario son el patrimonio de los holgazanes y malos labradores. Donde más generalmente se presenta dicha plaga es en los tabacales que ya son grandes: por lo que la vigilancia debe ser más constante, sin que este cuidado y la matanza de ellos altere el órden de escardas, cavas y riegos explicados anteriormente.

Tres son las clases de gusanos que atacan las plantas del tabaco, diferentes en tamaño, color, figura y dañinas condiciones, segun la clasificacion con que se conocen en Cuba: $\mathrm{Ca}-$ chazudo, Primavera y Cogollero.

El gusano Cachazudo se desarrolla $\nabla$ crece entre dos tierras y de ordinario junto al nacimiento de las raices del tronco, en donde por una fatalidad instintiva hacen sus ovaciones, se desarrollan despues, crecen y atacun vorazmente la parte más vital de la planta que sucumbe luego necesariamente. Contra este daño, si la mata es grande, ya no hay remedio, pues no puede reponerse ya la falta en el tabacal.

El gusano Primavera, fija sus ovaciones y se desarrolla en el tallo principal y peciolo de las hojas que, excepto la vena de ellas, las destroza enteramente ó mutila de modo que ya no pueden servir para capa.

El gusano Cogollero, se desenvuelve y crece en el cogollo mismo ú hojas superiores de 
la planta, á las que llaman los vegueros de corona, por ser las más desarrolladas, de mejor caliadad y mayor valor, las que roe y destroza enteramente.

Antes de deshijar ó en el mismo acto de hacerlo, deben cortarse las hojas roidas y estropeadas pará que no tomen la sávia en menoscabo de las otras buenas y sanas.

Queda brevemente explicado cuanto concierne al buen cultivo de la planta hasta que llegan á su madurez las hojas para el corte, de que hablaré en el capitulo siguiente; concluyendo éste con las enfermedades propias ó accidentales que afectan "á las matas de tabaco durante su permanencia en la tierra.

Las enfermedades de la planta del tabaco, unas son naturales y otras accidentales. Corresponden á las primeras aquellas que causa la mucha y constante humedad del terreno produciendo una verdadera hidropesía, que hace languidecer las matas y tomar sus hojas un mal color enfermo: si la humedad es excesiva sucle podrir las raices y la planta mue. re. Por el contrario, el esceso de calor, vientos sofocantes y largas sequías hacen tambien languidecer las plantas y áun sucumben por consuncion. Las demás enfermedades orgánicas del vejetal, científicamente consideradas, 
corresponden á la botánica y es cuasi inútil hablar de ellas en este lugar.

Las enfermedades accidentales son las vulgarmente llamadas viruelas entre los cosecheros: las blancas proceden de gotas de agua que fijas quedan en las hojas despues de una lluvia ó gran rocío, y un sol fuerte á seguida las condensa y manchan la hoja, Si son verdes, provienen de fuertes aguaceros cuando el labaco está para cortarse y el cosechero no tiene la prevision racional de dejar que se sequen las hojas antes do hacerlo; ó ya de cortar el tabaco con el rocío de la madrugada antes que el sol oree bien las hojas.

Las continuadas lluvías y aguaceros lavan ó quitan el melazo natural á las hojas, por lo que se dá el nombre de tabaco llovido y el que, por dicha causa, es de poca duracion en rama y expuesto, aún despues de elaborado, á picarse ó apolillarse con facilidad. Las otras manchas negruzcas y arroaladas del tabaco no son naturales y sí resultado de un mal beneficio, ó descuidado almacenaje.

Réstame sólo decir, que la matanza de los gusanos no admite dilacion y debe hacerse con la más atenta proligidad, repasando detenidlamente las matas una á una por entre los liños y levantando suavemente cada hoja para rer por uno $\mathrm{y}$ otro lado las que lo tienen $\mathrm{y}$ 
con las palmas de las manos, sin quebrar la vena principal, se matan aquellos.

Resumiendo: hecha la plantacion del tabaco en las tierras preparadas, en su cultivo se procederá por el órden siguiente. Primero, una escarda con el almocafre ó escardillo para romper la costra de la tierra y desahogar las plantas matando toda la yerba: despues, prévio un riego ligero ó lluvia, la cava, cuando las plantas están ya á la altura de la rodilla: luego, cuando las matas están para florecer, el señalamiento para dejar las de semilla: en seguida el despunte y corta de hijos ó mamones: luego la bina, ó ligera cava para beneticiar las plantas y matar yerba: riegos de pié con oportunidad, escardas á mano, y mucha vigilancia para matar el gusano, si fatalmente aparece. La mucha y constante humedad enferma las plantas, y si es pantanosa ó por encharques, mueren. Para evitar las viruelas verdes en las hojas que luego resultan, no deben cortarse si no despues que el sol las haya oreado bien del rocío $\delta$ lluvia. 


\section{CAPITUlO V.}

DEL CORTE Y RECOLECCION.

La corta del tabaco es general, ó parcial: general, cuando se hace á la vez de toda una plantacion; y parcial, cuando sólo se cortan en ella las hojas que están en buena sazon. Es cuasi imposible que un tabacal se encuentre en igual estado de madurez en un mismo dia. La razon es, que todas las plantas no crecen ni se desarrollan sus hojas con la misma igualdad, aunque el tabaco sea de una misma clase y semillero, la plantacion en un mismo dia y cultivada igualmente, pues ni una misma superficie de terreno es enteramente igual, á veces muy diferente, ni los abonos $\mathrm{y}$ laboreo dan el mismo resultado en una misma tierra, ora sea por su accidental situacion geológica ú otras varias causas $\mathrm{y}$ fenómenos naturales. El resultado constante en toda clase de siembras y frutos es, que estos se producen con desigualdad, áun en una misma mata ó planta, y que sus hojas son diferentes en edad y situacion de un mismo tallo. Por lo que, es 
lógico, exacto y más útil al cosechero, ejecutar el corte del tabaco parcialmente: esto es, de las hojas en sazon y de la marera que luego explicaré.

El tabaco empieza, á madurar á los tres meses de su plantacion, con poca diferencia, y se conoce en la ostensible pérdida de su verde oscuro, en unas manchas amarillentas que aparecen en el anverso de las hojas, cuyo color se vá extendiendo progresivamente $\mathrm{y}$ acercando al de castaña claro mate: en las arrugas, que hacen desaparecer su brillante terso anterior y en que se ponen algo lánguidas, ásperas y quebradizas. La experiencia ha acreditado no ser conveniente el dejar que se madure enteramente en la mata; pues si bien es cierto que cuanto más maduro tiene más calidad, aroma, miga y duracion, tambien lo es que su fortaleza es mucha al tiempo de fumarlo $\mathrm{y}$ pierde algo en bondad y suavidad. Sin embargo, el tabaco maduro y bien beneficiado es el mejor.

Cuando una plantacion ó siembra empieza á indicar su madurez se procede al corte, haciéndolo en dias claros á que hayan precedido algunos secos y de calor; cuya operacion se ejecutará entrado ya el dia, con el fin de que las hojas estén muy enjutas y no lleven humedad al camarin ó casas de oréo; circunstancia importantísima para el buen beneficio, 
conservacion y mérito del tabaco. El más leve descuido en ello trae funestas consecuencias.

El corte se hará con la podadera ó cuchilla corva de que hablé y describí en el capitulo primero de la seccion primera, cuya herramienta, bien afilada, se coge con la mano derecha, y con la izquierda se asegura hácia abajo el tallo de la mata, á la que so cortan diagonalmente de abajo arriba, pedazos ó trozos que cada uno contenga dos hojas, á lo que llaman en Cuba mancuernas.

Conforme se van cortando se echan al suelo junto á la misma planta, en donde permanecen algun tiempo expuestas al sol para que se marchiten. Detrás del que vá cortando, otros vạn recogiendo el tabaco y poniendo las mancuernas en el brazoizquierdo á lo largo de él hasta el codo, de manera que una hoja caiga á un lado y otra al otro, las que sin quitar del brazo se pasan á unas varas delgadas como de dos brazas de longitud.

La operacion ésta es muy sencilla, pues no hay más que por bajo de la muñeca meter la punta de la vara y se sigue poniendo mancuernas en ella hasta llenarla y en la que se seca el tabaco en las casas de oréo y beneficio, de que hablaré á su tiempo. Tambien se hace uso de sogas, cuerdas ó bejuco con el mismo fin. 


\section{2}

En Filipinas se acostumbra cortar el tabaco hoja por hoja, las que, conducidas en carromatas al camarin de oréo, las ensartan una á una por el peciolo con delgadas varillas de caña, hechas prolijamente para ello, como de tres palmos ó más: en cuya entretenida operacion se ocupa la familia del cosechero de dia y horas de la noche, y despues cuelgan aquellas con órden y cuasi juntas de palos atravesados en todo el camarin, de lo que me ocuparé en el capítulo siguiente.

Se comprende el major tiempo que invierten tanto en la corta como en el empalillado de las hojas, cuyo entretenido sistema, si se quiere, es mejor que el de mancuernas, y por ello conveniente no alterarlo, habiendo hecho reseña del otro para el cosechero que quiera ensayarlo.

Hecho todo el corte del tabacal, sea por mancuernas ú hoja á hoja, con la hoz se cortan todas las matas de la plantacion á un palmo de la tierra y se hacen pequeños montones repartidos para darles fuego despues oportunamente. A muy poco, salen de los troncos cortados varios retoños, de los que no se dejan á lo más, si no dos, si el patron es muy robusto, los que crecen con suma rapidez si las raices no se resintieron al hacer el corte de la mata: y si se dá una cava removiendo la tierra al 
rededor de los troncos y un riego, entonces producirán hojas, si más cortas, de tan buenas condiciones como las del primer corte.

Pasados unos quince dias se despuntan los retoños de igual manera que se hizo al tabaco principal, no dejando á cada uno de aquellos si no cinco ó seis hojas, segun su robustez. Si se véser poca la semilla guardada del primer corte, pueden dejarse para ella los más sanos y de vigor. Hecho el despunte de los retoños, se deshijan despues, y cuando están maduras las hojas se hace el segundo corte. Las hojas de éste se conocen por ser más estrechas, más desigual uno de sus lados, la punta más aguda y ménos película en el reverso. Despues se cortan los tallos junto al tronco principal.

En terrenos de buena calidad y con tiempo favorable, se pueden dejar otros nuevos retoños para un tercer corte, y entonces no se dejan más que tres ó cuatro hojas, los que se despuntan y deshijan igualmente, cortando aquellas cuando están en sazon. Este tabaco es muy suave al fumarlo.

Al fruto del primer corte se llana principal: al del segundo, capaduras: $\mathrm{y}$ al del tercero, mamones.

Resumierido: el corte del tabaco es general, ó parcial: el primero cuando se hace á la vez de toda una plantacion: y parcial cuando es 
solamente de las hojas maduras: es decir, á los tres meses poco más ó ménos de trasplantado. No es conveniente dejarlo que madure del todo en los terrenos de primera calidad, por que resulta luego con excesiva fuerza al fumarlo, si cun mas miga, aroma y peso. El corte de la hoja se hará en dias bien claros despues de algunas horas de sol, y marchitas llevarán en seguida por mancuernas ó empalillado al camarin de oréo. Despues del primer corte se cortarán todas las matas á un palmo de tierra, se dá un riego y cavará ésta. Los retoños que salgan se despuntarán y deshijarán á su tiempo, no dejando si no dos á las plantas más robustas. con cuatro hojas. Despues del segundo corte, aún podrá darse un tercero con las mejores plantas, si el terreno es deprimera yel tiempo ayuda. Al fruto primero se llama principal: al segundo, capaduras: y al tercero mamones. 


\section{SECCION TERCERA.}

DEL BENEFICIO DEL TABICO.

\section{CAPITULO PRIMERO.}

DEL OREO Y DEL PILONAGE.

En la precedente seccion he explicado todo lo necesario para el buen cultivo del tabaco en el campo: empero como no sean bastantes para su aceptable consumo las mejores condiciones naturales, necesario es modificarlas por medio del beneficio artificial; así que, tan importante es al cosechero saber cultivar bien el tabaco como las diferentes operaciones para su beneficio, pues de éste penden sus buenas ó malas condiciones para la elaboracion y el consumo. 
La prueba evidente de esta verdad son las inferiores del tabaco filipino comparado hoy con el de Cuba, donde se beneficia con esmero é inteligencia. Por ello tanta diferencia.

La primera operacion, despues del corte de las hojas, es orear éstas en las casas ó camarines de beneficio, y de ningun modo ni por causa alguna en las habitaciones ó viviendas como suele hacerse por algunos cosecheros de Filipinas.

Los camarincs de beneficio, á los que llaman los cosecheros cubanos "casas de tabaco," deben estar independientes de las viviendas y 10 más cerca posible de los tabacales. Su construccion debe ser un cuadrilongo de la capacidad conveniente para contener las periódicas cosechas; de una anchura proporcionada, de un solo piso $\mathrm{S}$ de la altura á propósito para que holgadamente puedan colgarse de cuatro á seis hileras de varas ó cuerdas de tabaco, sin que las puritas de las hojas bajas toquen al suelo, pues entre éste y aquellas es necesario que quede el espacio preciso para visitar ó registrar la cosecha y ejecutar las demás operaciones indispensables. El suelo debe estar baldosado ó entarimado con tablas, ó bien cubierto con tejido de cañas rajadas: por ningun motivo encalado ni en terrazo.

Dichos edificios deben ser de mampostería 
$\delta$ de tabla, muy bien cubiertos de las lluvias y tempestades, perfectamente hechos para que no entre aire cuando deban estar cerrados: con dos puertas anchas una á cada extremo y opuestas, con una hilera de rentanas iguales por uno y otro lado para dar la mayor ventilacion posible cuando convenga, y dividido el centro del edificio por si una siembra á la otra se adelanta que pueda darse con indepenclencia el beneficio correspondiente á cada una.

A falta de albañiles para edificar, de los que generalmente se carece en los pueblos cosecheros y áun de carpinteros para una buena construccion, pueden hacerse los camarines de oréo con buenos harigues de madera y cerrarlas con tejido bien hecho de caña rajada, dejando los claros convenientes para ventanas iguales unas frente á otras, y los de las dos puertas opuestas una á otra tambien. Despues se recubren por fuera los cuatro lados del camarin sobreponiendo al tejido de caña una capa de nipa ó de cogon, y con buenos tapancos de quita y pon se cierran los claros de ventanas y puertas. Excusado advertir que el quizame y techado debe hacerse con solidez y sin claros por bajo para que no entre aire ni polvo.

Al construirse dichos camarines ó casas de beneficio deben colocarse en el centro y á distancias iguales, pilarotes ó harigues derechos 
que sirviendo para sostener el techado, á la vez tambien para clavar en ellos ó atar con bejuco horizontalmente palos ó maderas largas, á igual altura unas que otras, sobre las que se ponen las puntas de las varas de mancuernas, ó se atan las cuerdas del empalillado con hojas de tabaco para su oréo. A dichas maderas llaman los americanos barreras.

Construidas las casas de beneficio de la manera que acabo de decir, reporta al cosechero ventajas de suma importancia, pues aprovecha más la cosecha, economiza tiempo y jornales, lo beneticia mejor, lo tiene más resguardado, conserva bien, y por consecuencia, saca más utilidad. Es de advertir, que no deben construirse las casas ó camarines de beneficio en sitios bajos ni húmedos, sí en los más secos y ventilados.

En Filipinas, que decirse puede, lo hace todo la benéfica naturaleza del clima, benefician del siguiente modo. Cortan de la mata hoja á hoja, y ensartadas despues una á una en delg̣aditas varillas de caña hechas á propósito, á que llaman empalillar, las cuelgan despues con bejucos tirantes dentro de los camarines y áun de las viviendas, ó bajo cualquier mal sombrajo al que ellos dan nombre de camarin de oréo. Estos consisten en cuatro cañas gruesas ó palos clavados en la tierra, con 
un mal techadillo de cogon ó nipa, cuyo mal sombrajo queda al libre paso de los cuatro vientos y áun entrada del sol, que abandonan despues de haber servido en la cosecha.

Resultado: que al tabaco dá el sol, el aire y las aguasviento por todos lados, cuyos perjuicios evidenciaré más adelante. No son sólo estos, sí que tambien el de los animales; pues ya saltan encima de las hojas al oréo las gallinas $\mathrm{y}$ el gallo ¡de maldicion! ya pasa por debajo el carabao ó en los harigues rasca el caballo y los cerdos sestean bajo el tabaco, 10 que aquellos indigenas ven con la más indiferente tranquilidad.

No continuaré haciendo mérito de todas y cada una de las rudas operaciones que en Filipinas se practican hoy, para el mal beneficio que allí dan al tabaco en rama, porque sería largo y enojoso. Basta con lo apuntado someramente para comprenderlo y los grandes perjuicios que ocasiona à la riqueza pública.

Construidos los camarines ó casas de beneficio en los términos y de la manera anteriormente dicho, cuando la recoleccion se vá acercando, deben repararse los desperfectos que haya, limpiarse el polvo y toda suciedad, ventilarlos y dejar en buen estado para recibir el tabaco.

Ya se traigan desde el mismo tabacal lle- 
nas las varas con mancuernas, ó empalilladas las hojas, se irán colocando con órden en las barreras más bajas ó maderas horizontales, para cuyo fin, ya dije, se dejaba libre en las dos puntas como dos palmos. Si se hace uso de cuerdas ó de bejucos sin partir, quedará en sus extremos lo bastante para atar muy tirante, pues el mucho peso de las hojas verdes hace que éstas graviten más en el centro, se junten demasiado $\mathrm{y}$ sobrevenga una fermentacion peligrosa.

Las cuerdas ó varas cargadas de tabaco se apretarán ligeramente unas con otras al colocarse, ó atar en las maderas horizontales más bajas con el fin de excitar el sudor; en cuyo estado permanecerá dos ó tres dias sin que pase jamás de cuatro, que es el tiempo bastante para ello y primer acto de beneficio. Despues se separarán aquellas algo más, se aclararán un poco las hojas y se elevarán á la barrera ó. madera superior para que orée y seque el tabaco, teniendo cuidado entónces que unas á otras no se toquen para evitar la fermentacion húmeda que podría ocurrir con grandísimo perjuicio de la cosecha.-A las manchas negruzcas que en tal caso aparecen en la hoja llaman los cosecheros filipinos boog.

Si acontece á los quince ó veinte dias, despues de estar colgado el tabaco en las casas de 
beneficio, notarse alguna humedad, se abrirán las puertas y ventanas, si el tiempo no es lluvioso, para dar cuanta ventilacion sea posible y se distancian más las hojas. Si á los tres $\delta$ cuatro dias se advierte por el olor que no cede la humedad, entonces se encenderá fuego que no dé humo ni tufo en varios sitios, por ser uno y otro muy perjudicial al tabaco.

Si por los medios de la ventilacion y del fuego no cede la humedad, en tal caso, muy fatal por cierto, el único de salvacion es, sacar inmediatamente todo el tabaco al sol y tenerlo expuesto hasta que desaparezca enteramente aquella, se orée bien, y entonces se vuelve á meter en las mismas barras y colocar más distanciadas las hojas.

Para evitar el funesto caso á que acabo do contraerme, no debe olvidarse que antes del corte y recoleccion precedan dos ó tres dias secos, que se corte en dia claro y en las horas fuertes del sol; que permanezca expuesto á él un poco tiempo antes de recogerlo del suelo; que no coja despues rocío ni humedad, colgándolo lo más pronto en la casa ó camarin de beneficio para que le sobrevenga un buen sudor natural, despues del que se distanciarán las hojas y las varas ó cuerdas para que no toquen unas á otras, y se cierran las puertas y ventanas. Si el tiempo fuese muy caloroso, en- 
tonces se deja abierta una ventana para establecer alguna rentilacion, si bien poca: pero si fuese fresco, todo cerrado.

Así, progresivamente, se vá distanciando el tabaco para evitar que las hojas no se manchen ni peguen unas con otras, vaya sudando naturalmente y dando tiempo adelantado para seguir el corte en las plantaciones, hágase parcialmente ó general.

Como las operaciones de beneficio son todas urgentes y delicadas, visitará diariamente el cosechero su camarin ó casa de tabaco, para ver el estado en que se encuentra, y prevenir ó evitar cualquiera accidente de los que acabo de reseñar, cuyo cuidado tendrá especialmente los primeros treinta dias. Despues de este tiempo, poco más ó ménos, empieza el tabaco á presentar su color propio de castaña más ó ménos claro, segun la clase de tabaco, terreno en que se ha criado, método de cultivo, infiuencias atmosféricas y enfermedades que haya ó no padecido la planta; en cuyo estado se deja sin tocarle, pues su color y el olor bastan para saber si está bien.

Como la hoja toma color antes que su tallo y venas, se aguardará á que el de éstas iguale con el de aquella para continuar en las demás operaciones.

Pasado este primer período de beneficio, se 
espera á que la atmósfera esté algo húmeda ó que haya 1lovido, para que las hojas tengan la conveniente flexibilidad y se pueda manejar bien el tabaco sin perjuicio alguno j,or falta de elasticidad, y se procede á darle el pilon de la manera siguiente.

En el sitio ó rincon que haja más abrigado en el camarin ó casa de beneficio, como á un pié de altura del suelo, se formará un tablado como para cama, el que se cubre bien por igual con una tongada de paja larga de arroz, ó con esteras, ú otro equivalente de abriço. En el mismo acto se empieza á descolgar tabaco de las varas ó cuerdas, y con cuidado se ran juntando las hojas por las cabezas y tienden con igualdad sobre la paja con los palillos ó cabezas hácia fuera, y las puntas de las hojas hácia dentro, formando así por tongadas iguales una pila con toda simetría, sin huecos ni claros, la que se reviste despues todo alrededor con bastante paja, cogon ú otra cosa equivalente, $\mathrm{y}$ encima se ponen unas tablas sobre las que se cargan diez y ocho ó veinte arrobas de peso. Así, y de igual modo se van formando pilas de diez á doce quintales, y no más; en cuyo estado se dejará el tabaco bien abrigado.

Por medio de esta operacion ó apilonamiento, al que en Filipinas llaman mandala, se 


\section{4}

consigue consumir á la hoja parte del melazo, mermar la excesiva fortaleza natural que conserva, quitarle gran parte del amargor, adelgazarlo y afinar al tacto, adquirir tersura y flexibilidad, perfeccionar su color, y adquirir por igual miga y buena condicion.

El tabaco estará apilonado de diez á catorce dias segun el calórico que se haya desarrollado en el centro de la pila, cuyo grado no debe bajar de quince ni pasar de veinte $y$ cinco "Reaumur", lo que con exactitud se conoce por medio del barómetro y los cosecheros prácticos á la impresion en su mano metiéndola en el pilon.

Si del sexto al octavo dia se notare más calor en la pila del conveniente, se descarga algo y aligera el abrigo: por el contrario, si se advierte que le falta se abrigará más, para evitar en el primer caso que se arda por exceso, $y$ en el segundo que se quede sin el debido beneficio; uno y otro extremo perjudiciales. El demasiado calor, aunque no se arda el tabaco, si bien lo purga más y mejora, le hace perder algo de su peso.

Se llama tabaco ardido al que dicen "lutio» los cosecheros filipinos.

Al.tabaco que haya sufrido excesiva humedad ó fermentacion en el primer período de sudor y oréo, no se darán más que de cinco á 
siete dias de pilon, teniendo presente que el tabaco filipino es propenso á fermentar, como la experiencia tiene acreditado.

Resumiendo: para dar al tabaco en rama el primer beneficio de oréo y sudor se ejecutará en camarines bien construidos en sitios no húmedos y ventilados, aisladamente, dentro de los que se colgará con órden la hoja fresca y marchita yá, algo juntas las mancuernas ó palillos en los dos ó tres dias primeros, para excitar el sudor. A los tres ó cuatro se distanciarán, para que empiece á orear y paulatinamente á secarse, teniendo cuidado entonces que no toquen unas á otras para evitar fermentacion. Si se nota alguna humedad se dará la conveniente ventilacion y distanciarán más. Si nocede, más ventilacion y hacer fuego sin humo ni tufo dentro del camarin, para que ayude á secar la atmósfera. Si no se consigue, se descolgará al momento todo el tabaco y soleará fuera, volviéndole á colgar dentro cuando esté bien enjuto. Si durante el sudor arreciáran calores fuertes, se abrirá una ventana para establecer alguna ventilacion. Se esperará á que la vena iguale su color con el de la hoja. Despues, en tiempo húmedo ó que dias antes haya llovido, se formará en el sitio más abrigado del camarin un provisional entarimado, con una buena tonga de paja lar- 


\section{6}

ga, cogon ú otro equivalente bien seco encima, se descuelga el tabaco y forma el pilon con él, colocando la hoja con las puntas hácia dentro, se carga de peso y abriga bien, en cuyo estado permanecerá de doce á catorce dias. La pila no contendrá más que unos diez á doce quintales de tabaco. Si al octavo dia se notase en el interior del pilon más calor del conveniente, se descargará y aligerará de abrigo, para que no se arda: por el contrario, si fuese poco aquél, se abrigará más para que tome sazon. Pasados unos veinte dias ya está en buen estado, se deshace la pila y dá comienzo al apartado y clasificacion de la hoja.

El detalle de todas y cada una de las manipulaciones que acabo de resumir, explicadas quedan anteriormente y tendrán presentes en la práctica los cosecheros. 


\begin{abstract}
CAPITULO II.
DE LA CLASIFICACION Y APARTADO.
\end{abstract}

La clasificacion y apartado del tabaco es la operacion maestra, por decirlo así, cuyo buen desempeño requiere los experimentados conocimientos de un racional y entendido sistema de cultivo y bəneficio. Su importancia afecta inmediata y directamente en Filipinas á los intereses del Estado, y á los del comercio de buena fé en segundo lugar: por lo que es importante en la práctica ejecutar aquella en los términos y modo que detalladamente voy á explicar; prévias algunas indicaciones pertinentes.

Diferentes son las denominaciones con que en América se clasifica el tabaco: libra, quebiado, puntas, injuriado de 1. ', injuriado de 2. ${ }^{a}$, injuriado de $3{ }^{\mathrm{a}}$, pajurrias y capaduras, cuyos nombres y clasificacion no se conocen en Filipinas, en donde la Hacienda lo recolecta bajo las reglas que establece.

La clasificacion y apartado se ejecutará del modo siguiente. En un sitio despejado y limpio que haya bastante luz dentro del mismo 
camarin ó casa de beneficio, y lugar que no pase aire, se extenderá una grande estera y sobre ella formará un regular monton de gavillas de hoja tomadas del pilon: y sentado frente á él el clasificador empezará á coger mancuernas ú hoja empalillada y á separarìa por clases, haciendo varios montones á derecha é izquierda hasta terminar la clasificacion; y así sucesivamente de toda la hoja del pilon. En tanto no se concluya se dejará éste en el mismo estado que se encuentre hasta terminar la operacion.

Conforme vá aumentando el clasificador los montones junto á sí, en los sitios préviamente destinados, se irá colocando la hoja separadamente por clases, si á la vez de clasificar, otras personas no se ocupan en ir encabezándola para el gavilléo, de que me ocuparé en el capítulo siguiente.

Durante la clasificacion y apartado se procurará que no dé aire á la hoja, pues se reseca y perjudica luego al hacer y atar los manojos para el gavilléo y segundo beneficio.

La concisa brevedad de este capitulo excusa de resumir lo que contiene. 


\section{CAPITULO III.}

DEL GAVILLEO Y SEGUNDO BENEFICIO.

Hecho el apartado y clasificacion en la forma explicada en el capítulo anterior, á cuya operacion llaman los americanos escojer, se procederá á encabezar la hoja formando con ella pequeños manojos que contengan, segun clase, el número de hojas preceptuado por la Hacienda para el aforo del tabaco, é igualadas las cabezas del peciolo de la vena principal se atarán ligeramente. Despues, se forman con ellos las gavillas de la manera siguiente.

Reunido con mucha igualdad y todas las cabezas juntas, el número de manojos ó manos designado para formar una gavilla, se atarán suavemente por dichas cabezas é irán poniendo en un sitio limpio, no húmedo y en el que no haya mucha ventilacion, por clases y con la debida separacion.

Acto contínuo y deutro de la misma casa ó camarin, se van formando simétricos montones sobre una gran capa de paja de arroz ó de cogon seco, encima del entablado de que hice 
mérito en el anterior capítulo primero para el apilonamiento del primer beneficio. Para éste, que es el último que el cosechero debe dar al tabaco en rama, los predichos montones no contendrán si no de cinco á seis quintales de hoja, formados al mismo tiempo de la operacion con simetría y las cabezas de aquella há. cia á fuera, á cuyo beneficio se llama dar el betun 5 blandura y ejecutará del modo siguiente.

Lo primero es preparar el betun, y para ello se toma una proporcionada cantidad de buena hoja de las más rotas 6 mutiladas, que sean de la mejor calidad y aroma, las que, dentro de una vasija nueva, bien limpia y sin olor alguno, se echan en infusion con agua limpia, en la que permanecerán macerándose tres 0 cuatro dias y aún cinco, si el tiempo no es caloroso.

Si las hojas escogidas para hacer el betun, por haberse lavado ó llovido la cosecha en el campo, careciesen de buena calidad, entonces se dejarán dos dias más en la infusion hasta que se produzca fermentacion, cuyo olor y sabor lo indicará ésta con exactitud.

Si el tabaco á que darse vá el betun es de mucha calidad y fortaleza, entonces no se dejarán tantos dias las hojas en infusion.-Si al que vá á darse dicho beneficio hubiese sufrido 
excesiva humedad al sudar en el oréo, ó en el pilon, entonces bastarán dos ó tres al preparado del betun. Para dar éste se ejecutará del modo siguiente.

En un sitio no húmedo y poco ventilado, sobre el mismo entablado y en los términos explicados al principio, se extiende una estera y rocía por igual con el betun preparado, á seguida se pone encima una tonga de gavillas, con las puntas hácia dentro, y sobre ella se rocía otra vez. Vuelve á ponerse otra tongada y rocía lo mismo que antes; v así progresivamente se vá formando la pila hasta en la cantidad de quintales dicha. En seguida se tapa ó cubre y permanece así veinte y cuatro horas, que pasadas, se desabriga y abre el monton para el manojeo, que explicaré en el siguiente capítulo.

Repetiré con insistencia, que todas las operaciones de beneficio es necesario ejecutarlas con exactitud, oportunidad y esmero, pues acontecería, en caso contrario, que en lugar de mejorar las inferiores condiciones del tabaco, inutilizarle; y al que las tenga buenas hacerle perder éstas. Por lo que, no debe el buen cosechero fiar la ejecucion de tan interesantes manipulaciones al cuidado indiferento de otras personas; no olvidando, que con ello puede aventurar el resultado de la cosecha en 
perjuicio de sus intereses, que á la vez son tambien los del Estado.

Lo explicado sobre el gavilléo tiene aplicacion inmediata en las colecciones de Filipinas, por serle indiferente á los cosecheros formar las gavillas con el número de manojos que prescriba la Hacienda para el recibo y pago del tabaco.

Resumiendo: el último beneficio que se dará al tabaco es el de blandura ó betun, con hojas de buena calidad y aroma para darle una $y$ otra, rociándolo con la infusion de aquellas; por tongadas formando pila de cinco á seis quintales y abrigándola, en cuyo estado permanecerá veinte y cuatro horas, despues de cuyo tiempo se desabriga, abre y queda listo para el manojén y enfardamiento de que hablaré en el siguiente capítulo.

\section{CAPITULO IV.}

DEL MANOJÉO Y ENFARDAMIENTO.

Pasadas las veinte y cuatro horas de estar el tabaco en blandura, se destapa y abre el monton y procede á manojear, como se dice en América, con exactitud. El manojéo se eje- 
cuta de este nodo.-Extendidas las gavillas sobre una estera en el suelo, se toman cuatro de ellas $\mathrm{y}$ juntan por las cabezas, sujetando con las rodillas, y se ata por tres partes con boja de palma, saja de plátano ú otro filamento equivalente. La primera atadura se hace en las cabezas de la hoja; la segunda en el centro, y la tercera, algo ménos apretada, cerca de las puntas.

Conforme se vá manojeando se amontonan con regularidad en sitio seco, para que no se desmejoren ó inutilicen las puntas si se dejan los manojos rodando por el suelo. Acabada esta primera operacion, ó á la vez si hay gente bastante, se procede al enfardamiento, á que llaman en Cuba enterciar, $y$ en Filipinas oficialmente jenfardelar!!

Para enterciar bien un fardo de tabaco rama, se clavan en el suelo ocho estacas fijas $\mathrm{y}$ muy derechas, á la misma distancia y formando un cuadrilongo rectángulo segun la prévia medida señalada, ó que sea costumbre. Dentro se pone una estera de filamentos herbáceos que con abundancia se producen en los trópicos, ó saja seca de hojas de plátano, como se acostumbra hacer en Filipinas.

Extendida la estera ó la saja en el fondo y por los lados con la suficiente extension para cubrir tambien por encima el fardo de tabaco, 
se pasan por debajo y á distancias iguales cuerdas ó bejuco partido de bastante consistencia para atar bien el tercio. Despues, se van colocando las gavillis con toda curiosidad $\mathrm{y}$ esmero, teniendo cuidado de casar las puntas para evitar que se rompan con los golpes exteriores y el peso de almacenaje.

Así que hay dentro el número de gavillas mandado, ó segun la costumbre, se cubre perfectamente con la estera ó saja para que el tabaco quede bien resguariado: y cargando encima el peso de uno de los hombres que ayudan, se echan las ataduras de modo que, si muy firmes para que no se deshagan, fáciles de desatar para la inspeccion de aforo, ó para la compra-venta del comercio.

\section{CApITUlo V.}

DEL PRENSADO Y ALMACENAJE.

Importante y esmerada operacion es la del prensado del tabaco en rama, porque si ésta se trata mal y sin el cuidado que requiere, al tiempo de formar los tercios para darles prensa, la hoja esperimenta gran perjuicio, especialmente si corresponde á la de capa. Por con- 
siguiente, tanto los fardos de coleccion como los tercios, deben prepararse unos $\mathrm{y}$ otros en los camarines de depósito de las colecciones con todo cuidado y proligidad por los empleados del ramo, para no perjudicar los intereses del Tesoro: Estas prevenciones se tendrán más en cuenta en las colecciones de Cagayán é Isabela, en las que el prensado se ejecuta obligatoriamente con los vecinos de los pueblos no cosecheros, y con presidiarios.

En la preparacion de los tercios para prensar, se pondrán las gavillas de hoja en el cajon con todo cuidado, casando unas con otras prolijamente y con las puntas hácia dentro, en el número necesario de ellas para formar tercio, y entonces, bien dispuesto todo, se le dará la presion conveniente hasta reducirlo al cuadrado cúbico establecido.

De no hacerse así, y echar las gavillas de cualquier modo en el cajon, resulta destrozarse y remoler gran parte de las hojas, cuyos desperfectos son de importancia $y$ en menoscabo grande de los intereses de la Hacienda. -Sobre los minuciosos detalles para el enfardamiento y atado de los tercios, no creo necesario ocuparme, por ser muy duchos y entendidos los indigenas en ello.

Despues de prensados los tercios se almacenan, formando con ellos regulares pilas con 
separacion por clases, de cosecha, y pueblos de donde procede, colocándolos sobre tablamentos que no toquen al suelo, generalmente de terrazo, ó sobre buenos cncañados dobles con alguna saja por encima, en cuyo estado quedará para acabarse de mejorar el tabaco con la calentura natural que en la misma pila se desarrolla.

Si por el olor se nota en las pilas alguna, aunque ligera fermentacion, se deshará al momento y dará por aquel lado del camarin de depósito más ventilacion para que desaparezca aquella, y despues se vuelven á apilar los fardos ó tercios con el mismo cuidado que antes se hizo; evitando el innecesario y perjudicial volteamiento de las pilas con la repeticion que la ignorancia de los empleados del ramo ejecuta hoy en daño y menoscabo de los intereses del Tesoro público.

Dentro de los camarines de coleccion, ni en los depósitos, se encenderá fuego de ninguna clase, ni meterá en ellos cosa alguna que produzca mal olor, evitando, cuanto sea posible, la entrada de polvo exterior, no hacerlo dentro de los mismos, ni se regará tampoco el sue10. La entrada en ellos de toda clase de animales, se prohibirá por el almacenero y faginantes, los que de dia ni de noche permitirán se entre con luz artificial. 
Cuando se remuevan los fardos y tercios, ó saquen del almacen, se tratarán con cuidado y no tirarán al suelo, ni los arrastrarán ó llevarán rodando á bordo de los buques de conduccion interior ó exterior, como indebida $y$ perjudicialmente para la Renta se suele hacer en los depósitos de embarque, por la tolerancia y descuido de algunos negligentes almaceneros, cuya reprensible conducta se tolere por el aforador del distrito ó partido, encargado del prensado del tabaco.

\section{EPÍLOGO.}

A los cuatro meses de benéficiado y almacenado el tabaco, está ya en buen estado para su elaboracion en las fábricas. 



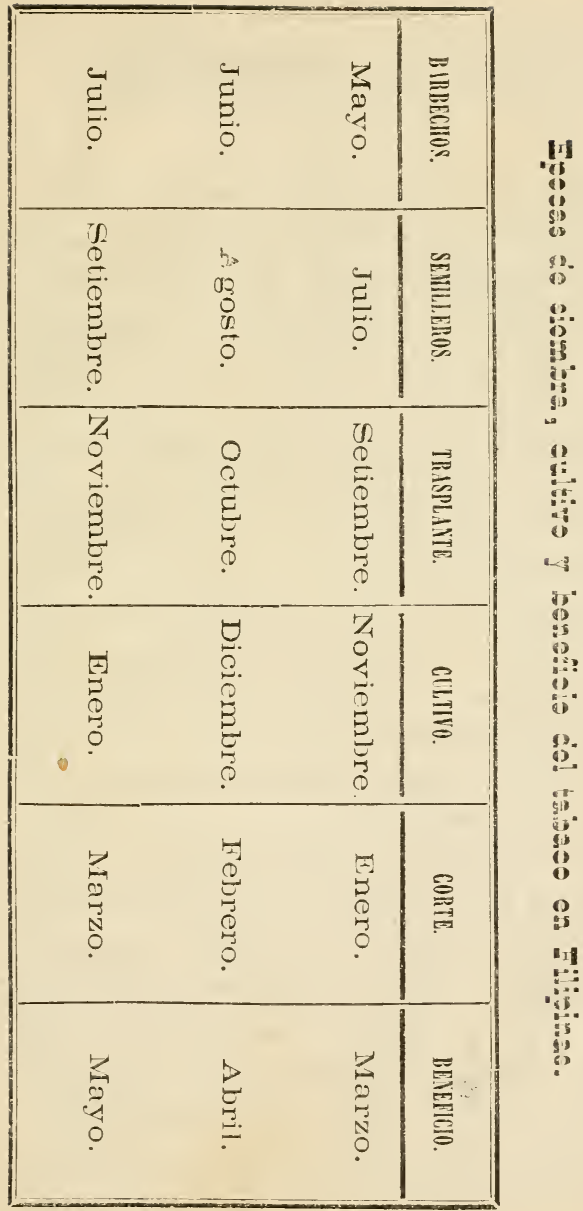





\section{DESCUBRIMIENTO DEL TABACO.}

Diferentes escritores se ocuparon del origen ó descubrimiento del tabaco sin convenir en el punto que lo fué. Algunos aseguraron que dicha planta fué descubierta en la isla de T'abago y que de ella tomó su nombre, cuyo error contradice la tradicion y la historia; pues cuando dicha isla fué ocupada por los holandeses en 1632, el uso del tabaco era yá bien conocido en América ciento cuarenta años antes, y sabido que dicho nombre era el que daban los indios primitivos á un canuto delgadito y bien afinado, como un palmo de largo, del que se servian introduciéndolo en cualquiera de los orificios de la nariz, para aspirar con él el humo de las hojas secas y algo machacadas de dicha planta, que quemaban sobre áscuas sin llama, para amodorrarse ó embriagar. Tambien usaban, para el mismo fin, de dicho instrumento ó pipa hecho en forma de $Y$, cuvos extremos introducian por ambos narigales $\mathrm{y}$ por el otro aspiraban el humo.

Se opinó por otros escritores que dicha planta habia sido descubierta en la parte occidental de la América del Norte, en la region denominada La Florida, sin tener presente que 


\section{2}

el descubrimiento de ésta fué bien posterior al dia 4 de Noviembre de 1492 en que el inmor tal Colon descubrió y posesionó de la isla de Cuba, desde cuya época se conocia ya la planta y los usos que de ella hacian los indigenas.

En lo que no hay duda es, que llevados de la codicia algunos hombres de guerra de aque. lla memorable primera expedicion, Rodrigo de Jeréz, vecino de Ayamonte, Luis de Torres, hebreo bautizado, y otros de sus compañeros de armas, se internaron algunas leguas en dicha isla buscando minas ó placeres de oro hasta una ranchería de indios llamada entonces Camaruei y posteriormente hasta hoy, Puer. to-Príncipe: y en una gran llanura entre el rio Cauncio y una poblacion del mismo rombre, fué en donde vieron por vez primera las plantas de cohiva, cogiva, ó coviva, como la llamaban aquellos indigenas, y el uso que de ella hacian para embriagarse ó narcotizar; observando tambien la aplicacion medicinal de sus hojas verdes para la curacion de úlceras y otros padecimientos morbosos.

Lo cierto es, que confundiendo aquellos aventureros el nombre indigena tabaco, que los indios daban al canuto hueco de que se servian para aspirar el humo de las hojas secas quemadas de la cohiva, con el de esta planta. continuó siéndolo aquél hasta hoy. 
Respecto á su introduccion en Europa, no cabe duda alguna, en consecuencia de lo dicho. que los españoles de Colon y de sus capitanes sucesores fueron los primeros que la importaron, si con diferente fin y objeto al principio: esto es, como yerba medicinal, de que se sirvio entonces útilmente la Farmacopea alopática, en vista de repetidos ensayos y experimentos en determinadas enfermedades y padecimientos.

Con efecto; en el año de 1560, siendo enfermo un predilecto paje de Catalina de Médicis, con varias úlcerıs peligrosas, Juan Nicot, embajador de Francia en la córte de Portugal, envió como obsequio á dicha Reina unas plantas de tabaco, con cuyas hojas curó y sanó aquél. Tan eficaz y buen resultado contribuyó á dar más fama $y$ crédito al tabaco, como planta medicinal, y los repetidos ensayos que de ella se hicieron con buen éxito despues, acentuó más su nombradia en Europa, dándola entonces vulgarmente el nombre de Yerba Real, y posteriormente el de nicosiana, derivado del apellido Nicot: y es con el que técnicamente lo adoptó la ciencia botánica para la familia de vejetalesá que corresponde, en clasificacion, el tabaco. 


\section{ADEITDICE.}

La teoría y enseñanza práctica que contiene el precedente Manual para el bien cultivo y beneficio del tabaco en Filipinas, excepcion hecha en esta peninsula de las regiones muy frias y zonas de secano excesivamente cálidas ó salitrosas, en las demás localidades húmedas y terrenos de regadío, con aguas no minerales, tienen aquellas útil aplicacion para cl cultivo y beneficio del tabaco: teniendo especial cuidado en la exposicion de las tierras, y en hacer los semilleros en sitios abrigados del Norte, á sol saliente y en la misma épocaque se hacen los de tomates, berenjenas $y$ pimientos.

En las zonas templadas é islas Baleares podrán hacerse dos cortes de tabaco desde Marzo á Setiembre; y en las islas Canarias, hasta tres, con sobrado tiempo para beneficiar la hoja en las casas de oreo construidas al efecto.

En libro separado explicaré todo lo relativo á la elaboracion del tabaco y su envase en las fábricas, desde que en ellas se recibe la hoja hasta que en puros, cigarrillos y picadura sale de las mismas para su venta y consumo: con un apéndice histórico del monopolio oficial de la Renta del tabaco en España, desde su origen hasta hoy. 


\section{ÍNDICE.}

SECCION PRIMERA.

NOCIONES GENERALES DE AGRICULTURA APLICADAS AL CULTivo DEL TABACO.

Págs.

Capítulos I.-De las herramientas y aperos..... 7

- II.-De los animales para el trabajo.... 18

- III.-De la roturacion de los bosques... 26

$\quad$ IV. -De la nivelacion y desecacion de los terrenos................... 34

y V.-Del laboréo y abono de las tierras.. 42 SECCION SEGUNDA.

DEL GULTIVO DEL TABACO.

Capítulos I.-Del clima y tierras útiles para tabacales................... 59

๖ II.-De la semilla y semilleros....... 6 .

" III.-Del trasplante y riegos........ 79

" IV.-Del cultivo y enfermedades de las plantas.................. 86

ע V. -Del corte y recoleccion........ 99 SECCION TERCERA.

DEL BENEFICIO DEL TABACO.

Capítulos I. -Del oréo y del pilonaje......... 105

ఎ II.-De la clasificacion y apartado .... 117

ఎ III.-Del gavilléo y segundo beneficio.. 119

ע IV.-Del manojéo y enfardamiento.... 122

" V.-Del prensado y almacenaje...... 12.

Épocas de siembra, cultivo y beneficio del tabaco

en Filipinas...................... 129 








cusis

or

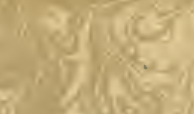
$y_{y} y=$

하단

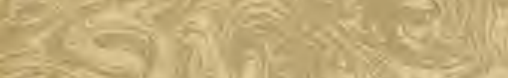

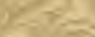

12.

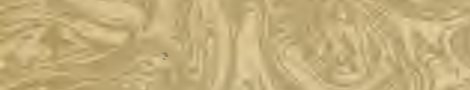

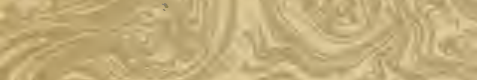

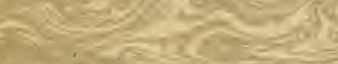

Wh $2=0$

$\mathrm{xp}$

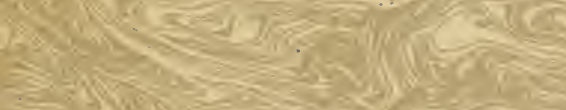

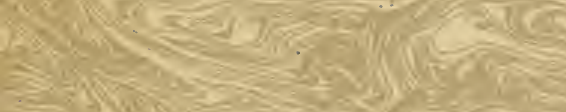

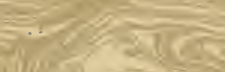

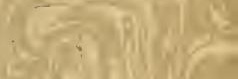

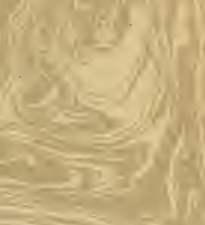

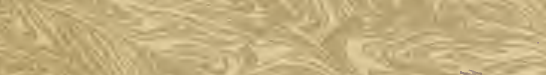

W.

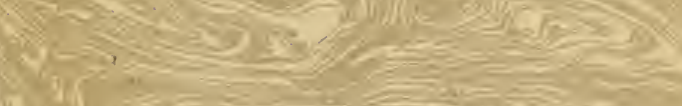

Mrase

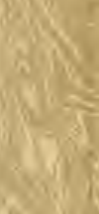

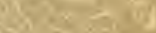

(1)

28

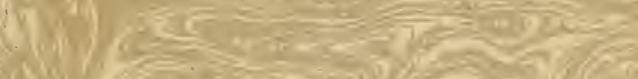

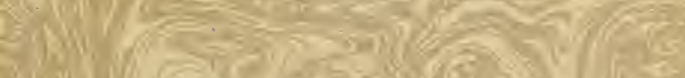

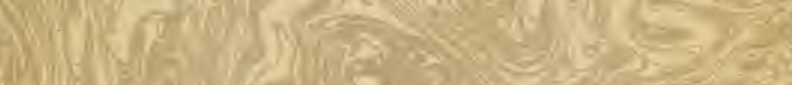

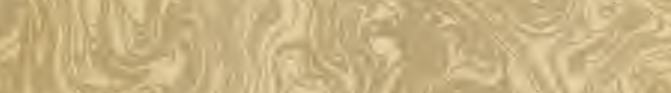

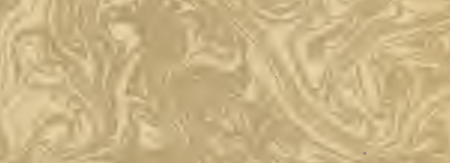

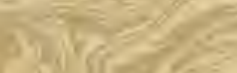

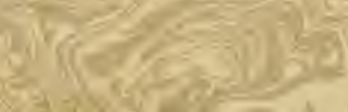

$\frac{2031}{2}$

$4^{2}=$ 
